\title{
Armed Conflict, Household Victimization, and Child Health in Côte d'Ivoire ${ }^{ \pm}$
}

\author{
Camelia Minoiu \\ International Monetary Fund
}

\author{
Olga N. Shemyakina ${ }^{ \pm \pm}$ \\ Georgia Institute of Technology \\ School of Economics
}

First draft: December 4, 2011

This draft: October 8, 2012

\begin{abstract}
We examine the causal impact of the 2002-2007 civil conflict in Côte d'Ivoire on children's health using household surveys collected before, during, and after the conflict, and information on the exact location and date of conflict events. Our identification strategy relies on exploiting both temporal and spatial variation across birth cohorts to measure children's exposure to the conflict. We find that children from regions more affected by the conflict suffered significant health setbacks compared with children from less affected regions. We further examine possible war impact mechanisms using rich survey data on households' experience of war. Our results suggest that conflict-related household victimization, and in particular economic losses, is an important channel through which armed conflict negatively impacts child health.

Keywords: human capital, child health, conflict, height-for-age, sub-Saharan Africa JEL classification: $\mathrm{I} 1, \mathrm{~J} 1, \mathrm{O} 1$
\end{abstract}

\footnotetext{
${ }^{ \pm}$Olga Shemyakina would like to thank Georgia Institute of Technology for financial support. We are grateful to the National Statistical Institute and the Ministry of Planning and Development in Côte d'Ivoire for their permission to use the 2002 and 2008 HLSS (Enquêtes sur le Niveau de Vie) for this project. We are grateful for helpful comments and discussions to Richard Akresh, David Bardey, Kelly Bedard, Sandra E. Black, Tilman Brück, Olivier Ecker, Fergal McCann, Adam Pellillo, Petros Sekeris, Emilia Simeonova, John Strauss, and participants at the 3rd Conference of the International Society for Child Indicators, 81st Southern Economic Association Annual Meeting, 7th Households in Conflict Network Workshop, AEA/ASSA 2012 meetings, CeMENT CSWEP workshop, the seminar at the Bush School of Government at Texas A\&M University, CSAE 2012, the $12^{\text {th }}$ Jan Tinbergen European Peace Science Conference, The Conference on the Economic and Social Consequences of Armed Conflict and Crime (Cartagena), and the 1st NOVAFRICA Conference on Economic Development in Africa. The views expressed in this paper are those of the authors and do not necessarily reflect those of the IMF or IMF policy, or those of granting and funding agencies.

Corresponding author: Olga Shemyakina, School of Economics, Georgia Institute of Technology, Atlanta, GA, 30332-0615, USA, olga.shemyakina@econ.gatech.edu, (323) 2293180.
} 


\section{Introduction}

The process of human capital accumulation, a key driver of long-run growth, is often derailed when countries experience large shocks such as natural disasters, social strife and armed conflict, adverse terms of trade movements, and economic downturns. Almost one third of developing countries have experienced civil warfare and violence during 2000-2008. ${ }^{1}$ Studies on the aggregate impact of conflict show that affected countries and populations adjust relatively fast and often return to their pre-conflict growth trajectories (Davis and Weinstein, 2002; Brakman et al., 2004; Miguel and Roland, 2011). However, a growing body of research on the micro-level consequences of conflict finds that children and young adults are particularly vulnerable to negative shocks. ${ }^{2}$ Some of these shocks, especially when experienced during early childhood, have lasting effects on later-life outcomes that are difficult to reverse.

Recent studies establish a robust negative association between armed conflict and child health (Bundervoet et al., 2009; Akresh et al. 2011; Baez, 2011; Akresh et al., 2012; Mansour and Rees, 2012). In this paper we look beyond the causal impact of armed conflict on child health and also explore the channels though which it operates. We make four contributions to the literature. First, we use nationally representative survey data collected before, during, and after the conflict to estimate its impact on child health. This differentiates our work from previous studies that typically rely on post-conflict surveys (de Walque, 2011). In addition, our postconflict survey was run in the year immediately following the end of the conflict, which enhances our confidence in the quality of responses to conflict-related questions. Second, based

\footnotetext{
${ }^{1}$ Based on data from Marshall (2010).

${ }^{2}$ E.g., Akbulut-Yuksel (2009), Bundervoet et al. (2009), Blattman and Annan (2010), Akresh et al. (2011), Chamarbagwala and Morán (2011), Shemyakina (2011), Swee (2011), Minoiu and Shemyakina (2012), Leon, (forthcoming), Mansour and Rees (2012), and Verwimp (2012).
} 
on unique data on war-related experiences available in the post-conflict survey, we construct measures of conflict-related household victimization that allow us to explore the mechanisms by which conflict impacts child health. Third, we determine how the effect of a regional measure of conflict, which we interpret as a covariate shock, varies with that of household-level victimization on child health, an idiosyncratic shock. Fourth, we contribute to the literature on gender bias in the face of negative shocks by examining gender differentials in the estimated impact using different sub-samples and specifications.

The shock under scrutiny is the 2002-2007 conflict in Côte d'Ivoire and the outcome of interest is children's height-for-age z-score, a commonly used indicator of long-run nutritional status and health (Martorell and Habicht, 1986). Our identification strategy relies on exploiting both temporal and spatial variation across birth cohorts in exposure to the conflict. Large health setbacks are observed for children from conflict regions and households victimized by the war. Height-for-age z-scores are on average between 0.2 and 0.4 standard deviations lower for children living in conflict regions compared to same-age children outside conflict regions. In the full sample, the stature deficit is more pronounced for children exposed to the conflict for longer periods of time. We find no systematic differences across genders. All our results are conditional on individuals surviving the conflict and remaining in the country.

While the absence of longitudinal data does not allow us to examine the well-being of the same households before and after the war, ${ }^{3}$ we exploit cross-sectional variation in self-reported household victimization levels to pin down the channels through which the conflict affects individuals. Among the shocks we examine, economic losses have a negative and statistically

\footnotetext{
${ }^{3}$ Panel data are rarely available for conflict-affected countries. When available, they are often collected after the end of the conflict (de Walque, 2011).
} 
significant impact on child health. Children in households whose head reports impaired health and being directly exposed to violence also have a stature deficit, but the estimates are not statistically significant. Furthermore, the impact of victimization is stronger for children living in conflict regions, suggesting that the effects of the idiosyncratic shock are amplified in regions affected by the covariate shock.

While most studies use data collected after the conflict, we are able to control for preconflict health differentials using data collected prior to the conflict as well. The surveys we use are the 2002 and 2008 Household Living Standards Surveys (HLSS) and the 2006 Multiple Indicator Cluster Survey (MICS3) for Côte d'Ivoire. ${ }^{4}$ The 2008 post-conflict survey provides rich information on household experiences during the war which we use to construct measures of idiosyncratic exposure to the war. The covariate shock is captured with an indicator variable for conflict-affected areas identified using data on the exact dates and locations of conflict events from the Armed Conflict Location and Events Dataset (ACLED) (Raleigh et al., 2010).

In baseline regressions we control for household head, mother and child characteristics, province fixed effects, and month-of-birth fixed effects. We supplement these with a battery of robustness checks regarding the inclusion of province-specific trends to control for pre-existing trends in cohort health, the definition of the treatment and control groups, changes in sample composition, migration, selective fertility, and child mortality. Our results are robust to these tests. We also apply a placebo test to survey data from an earlier period to address the concern that conflict locations may be non-random. Finally, we look for correlations between selfreported victimization and observables to investigate whether victimized households are a select

\footnotetext{
${ }^{4}$ See the Data Appendix for more information.
} 
sample targeted for violence. Again, we find that our results hold up and conclude that we can credibly attribute the identified effects to the armed conflict.

The remainder of the paper is organized as follows. In Section II we relate our study to previous work and describe the historical context of the Ivorian conflict. Section III presents the data, the estimation strategy, our baseline results, and the robustness checks. In Section IV we focus on conflict impact mechanisms. In Section V we further discuss the results and conclude. Additional results are available in an online appendix. ${ }^{5}$

\section{Literature Review and Historical Background}

\section{II.1. Previous Studies}

Our paper contributes to a large literature that stresses the importance of early childhood conditions for human capital accumulation and adult outcomes (see Currie, 2009; Almond and Currie, 2011 for surveys). For developing countries, Strauss and Thomas (1998) document a positive relationship between height and education, employment, and wages. Glewwe et al. (2001) and Alderman et al. (2006) show that poor nutrition hinders school performance and thereby decreases life-time income. Looking at the factors that influence child health, Baird et al. (2011) assemble survey data from 59 developing economies and show that short-term economic fluctuations increase child mortality and that female infants face the highest risk.

Further, our results contribute to the growing literature that documents a negative link between armed conflict and child health. ${ }^{6}$ Akresh et al. (2012) examine the consequences of the

\footnotetext{
${ }^{5}$ Available on www.camelia-minoiu.com/civ-onlineappendix.pdf. (Tables and figures in the appendix are labeled "A" for Appendix).

${ }^{6}$ A distinct literature examines the consequences of armed conflict on the health of young adults. For instance, Agüero and Deolalikar (2012) show that while the negative impact of the Rwandan genocide decreases with age at exposure in a sample of women, the effects are stronger for women who were adolescents during the genocide.
} 
Ethiopian-Eritrean war on the height of young children in Eritrea and find that children exposed to the war are shorter by 0.42 standard deviations compared to the reference population. Bundervoet et al. (2009) document an average impact of the Burundian war of 0.35 to 0.53 standard deviations, while Akresh et al. (2011) estimate a slightly larger coefficient of 0.64 standard deviations for children exposed to the pre-1994 Rwandan war. Our baseline estimates of the average effect of conflict on the height-for-age z-score of the war-affected cohort are in the same ballpark as the literature at 0.2-0.4 standard deviations.

We also add to the literature on human capital and economic development in West Africa. Several studies on Côte d'Ivoire focus on health in comparative perspective and provide a useful backdrop for our results. ${ }^{7}$ Strauss (1990) shows that in 1985 stunting rates in rural Côte d'Ivoire were half the African average, but twenty times larger than in the United States. Cogneau and Rouanet (2009) examine pre- and post-colonial stature and find that health improvements during the colonial period occurred due to fast urbanization and improvements in cocoa production. Other studies focus on macroeconomic shocks. Thomas et al. (1996) quantify the effects of the 1980s adjustment policies in Côte d'Ivoire on child and adult health. Across a range of measures they find that the health of children and adults was hindered by programs of macroeconomic adjustment. Larger negative effects are documented for males, children and adults. Cogneau and Jedwab (2012) use the 1990 reduction in administered cocoa producer prices as an exogenous shock to farmer welfare and compare child health and education

Domingues (2010) finds that the impact of the protracted Mozambican war on height is stronger for women exposed to the war earlier in life.

${ }^{7}$ Jensen (2000) examines investments in child education and health in the face of weather shocks to agricultural income in Côte d'Ivoire and finds adverse effects on enrollment and short-run measures of nutritional status. 
outcomes before and after the event. They find that human capital investments are procylical and that there is greater bias against young girls during times of economic stress.

\section{II.2. Spatial and Temporal Intensity of the 2002-2007 Ivorian Conflict}

Côte d'Ivoire, the world's leading exporter of cocoa, enjoyed a long period of political stability and economic development following its declaration of independence in 1960. With an average real GDP growth rate of 4.4 percent during 1965-1990, Côte d'Ivoire became an economic powerhouse in West Africa and an attractive destination for foreign investment and migrant workers from neighboring countries. ${ }^{8}$ Political unrest followed the death of long-standing President Felix Houphouet-Boigny in 1993 and a number of coups d'état took place during the 1990s. A military coup in December 1999 caused a deep sociopolitical crisis.

The root causes of the 2002-2007 Ivorian conflict can be traced back to widespread discontent over land ownership and nationality laws (in particular, eligibility rules for individuals running for office), ${ }^{9}$ and voting rights affecting the large population of foreign origin living on the territory of Côte d'Ivoire. ${ }^{10}$ As tensions flared, the armed conflict began in September 2002 with multiple attacks by rebel forces representing mostly the Muslim, northern parts of the country. Violence erupted in several cities, including Abidjan in the south, Bouaké in the center,

\footnotetext{
${ }^{8}$ By end-1998, more than a quarter of the population consisted of foreign workers, mostly of Burkinabe and Malian origin.

${ }^{9}$ The 2000 constitution stipulated that presidential candidates be born in Côte d'Ivoire from Ivorian parents.

${ }^{10}$ The seeds of the conflict were sown in the mid-1990s when the concept of "Ivoirité" (or "Ivoiry-ness") entered the political discourse. As the country has an ethnically-diverse population, a large share of foreign workers, and many naturalized first- and second generation Ivorians, the denial of voting rights, land rights, and hostility towards migrants led to tensions that culminated in the 2002-2007 conflict (Sany, 2010).
} 
and Korhogo in the north. ${ }^{11}$ Throughout the conflict the country remained essentially split into two, with the northern and western parts of the country under the control of rebel forces (Forces Armées des Forces Nouvelles) and the southern part under government control (UK Home Office, 2007).

In the rebel-controlled north, access to basic public services such as electricity and water, health clinics, and schools was severely impaired during the conflict. According to surveys analyzed in Fürst et al. (2009), the three most important conflict-related problems reported by households in the western province of Man were health problems (48 percent), lack of food (29 percent), and impaired public services (13 percent). Precarious water distribution during the conflict compounded existing health problems, with reports that only one fifth of water pumps in the rural north were operational (UNOCHA, 2004). Education services were also severely disrupted in the north, where 50 percent of school-age children were deprived of education by 2004 (Sany, 2010). It is estimated that 70 percent of professional health workers and 80 percent of government-paid teachers abandoned their posts in the northern and western parts of the country (UNOCHA, 2004; Sany, 2010).

While the first years of the conflict were marked by more violence than the latter period, the Ivorian war stands out as a long and relatively low-intensity conflict. Records indicate that it caused some 600 battle fatalities per year in the initial phase compared to ten times as much in the average civil war in the Battle Deaths Dataset (UCDP/PRIO, 2009). It also led to large population movements and had a severe economic impact. Per capita GDP growth during 20022007 was on average -1.5 percent, the second lowest in the region, and the poverty rate rose sharply. Peace talks and negotiations held throughout the conflict culminated in March 2007 with

\footnotetext{
${ }^{11}$ See Figure A1 for a map of Côte d'Ivoire.
} 
the signature of the Ouagadougou Political Accord, which marked the official end to the conflict. $^{12}$

To identify conflict-affected regions, we use information from the ACLED database on the exact dates and locations of violent incidents during the conflict, including riots, protests, armed battles, and violence against civilians. We match conflict events within each location and for each year to children's province-of-residence (at the time of the survey) and year-of-birth in the surveys. ${ }^{13}$ We define conflict regions as those provinces for which ACLED reports at least one conflict event from September 2002 to November 2007. Figure 1 depicts the spatial distribution of conflict events based on the ACLED dataset. With the exception of Abidjan, the economic capital of Côte d'Ivoire, provinces with a higher incidence of violence, shown in darker shades, are concentrated in the rebel-held, northern and western parts of the country.

In Figure 1 the western part of Côte d'Ivoire stands out as the area most affected by highintensity conflict (based on the frequency of conflict events). Several reasons may explain this pattern. First, fertile cocoa-growing regions of western Côte d'Ivoire had long-standing tensions between indigenous ethnic groups and non-Ivorians (mostly of Burkinabe and Malian origin) over property and land rights (Mitchell, 2011). Second, the region hosts large numbers of Liberian refugees who in the aftermath of the 1999-2003 Liberian Civil War settled in a special refugee zone extending over four western provinces. About one third of the population in these provinces is of foreign origin (Kuhlman, 2002) and foreigners were targeted during the

\footnotetext{
${ }^{12}$ A timeline of events based on the reports of the UN Mission in Côte d'Ivoire (ONUCI) is shown in Figure A2.

${ }^{13}$ Although the ACLED dataset reports the exact longitude and latitude coordinates of each conflict event, we perform the matching at the province level because the household surveys used in our analysis do not contain GIS information.
} 
conflict. ${ }^{14}$ Third, during the second phase of the conflict the western regions witnessed a large number of attacks by local militarized groups, including against United Nations bases and property (UNOCHA, 2006a, 2006b). ${ }^{15}$

\section{Data and Methods}

\section{III.1. Household Surveys}

The three datasets we use, the 2002 and 2008 Côte d'Ivoire HLSS and the 2006 MICS3, provide anthropometric information for 15,421 children aged 6-60 months at the time of each survey. Height-for-age z-scores are calculated using World Health Organization (WHO) Multicenter Growth reference datasets.

Summary statistics reported in Table 1 indicate that during the period of analysis Ivorian children lagged behind the international reference population, with average height-for-age zscores being lower by almost two standard deviations in the early survey and by 1.5 standard deviations in the later ones. Average height-for-age z-scores are also higher in conflict regions. Average age is between 31 and 37 months and does not differ significantly across surveys or between more and less affected regions. However, there are statistically significant differences in the share of children of various ethnicities and religions inside and outside conflict regions. In conflict and non-conflict regions respectively, 83-84 percent of mothers are married, while 52 and 65 percent of children reside in rural areas. Children from conflict regions are 8 percentage

\footnotetext{
${ }^{14}$ In particular, hostilities resurfaced in Côte d'Ivoire between the same ethnic groups which had fought on the Liberian side of the border during the 1999-2003 Liberian War. Several UN documents report hostilities in the Liberian community during the Ivorian conflict (UNOCHA 2003a, 2003b). According to McGovern (2011, pp. 207), both parties to the conflict often attributed especially violent events to Liberian militias.

${ }^{15}$ Chelpi-den-Hamer (2011) provides a detailed account of the motivations and activities of armed factions in western Côte d'Ivoire during the conflict.
} 
points more likely to come from poorer households. We include most of these variables as controls in our regressions and perform robustness checks to ensure that our results are not driven by these differences. ${ }^{16}$

\section{III.2. Baseline Specification}

We begin by estimating the following baseline difference-in-differences specification:

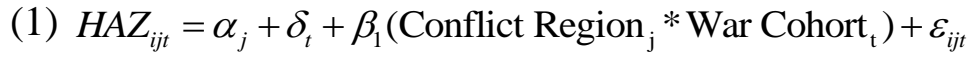

where $H A Z_{i j t}$ is the height-for-age z-score of child $i$ (aged 6-60 months) residing in province $j$

and born in year $t, \alpha_{j}$ are province fixed effects, $\delta_{t}$ are birth-cohort fixed effects (month-year of

birth), and $\varepsilon_{i j t}$ is a random, idiosyncratic error term. All regressions include dummies for gender and rural residence. The "War Cohort" variable refers to children measured in the 2006 and 2008 surveys who were thus exposed to the conflict at a young age or in utero. While the 2008 survey has data only for children born after the conflict, the 2006 survey contains data for children born before or during the conflict and measured during the conflict. Therefore, all children from this survey are included in the war cohort.

In Eq. 1, the main coefficient of interest $\beta_{1}$ captures the average impact of residing in a conflict region on the health of children in the war cohort. Controlling for province fixed effects allows us to account for province-specific unobserved characteristics and remove any bias caused by correlation between these characteristics and exposure to the war. Birth-cohort fixed effects control for global factors that simultaneously affect the health of each cohort.

In line with the literature on the effects of shocks in early childhood on health (e.g., Bundervoet et al., 2009; Banerjee et al., 2011; Akresh et al., 2012), we also estimate the

\footnotetext{
${ }^{16}$ Since migration information is unavailable in the 2006 survey, all results that refer to households' migration status use data from the 2002 and 2008 surveys.
} 
specification in Eq. (1) with province-specific trends (i.e., province dummies interacted with the year of birth). This specification allows us to control for pre-existing province-specific trends in cohort health $\left(\lambda_{j t}\right)$ hence to rule out the possibility that such trends contaminate our results:

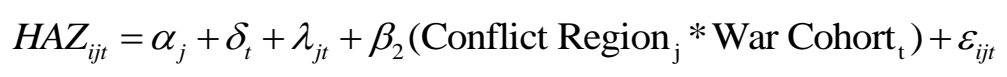

Then we consider additional specifications to exploit variation in the duration of exposure to the conflict. For instance we replace "War Cohort" with indicator variables for no exposure (reference category), exposure between one and 24 months, and exposure of at least 25 months, as well as a continuous measure of the duration of exposure to the conflict (in months). Children who were conceived or born after September 2002 are assumed to have also been exposed to the shock in utero. Thus, total exposure duration for them is the number of months in utero during the conflict plus their age in months. ${ }^{17}$ To allow for gender differentials in the impact of the conflict, we also estimate all specifications with interaction terms between the variables of interest and a female dummy. Finally, we assess the sensitivity of these baseline results to adding controls for child, household head, and mother's characteristics.

\section{Empirical Results}

\section{III.1. Baseline Regressions}

The baseline OLS regressions, presented in Table 2, indicate that children with in utero or early childhood exposure to the conflict and who lived in conflict-affected regions had height-for-age z-scores that were 0.250 standard deviations (s.d.) lower than children born during the same period who lived outside conflict regions (column 1). The estimated coefficient increases to 0.414 s.d. and remains statistically significant at the 5 percent level when we control for preexisting trends in cohort health (column 2). In columns 3-4 we replace "War Cohort" with

\footnotetext{
${ }^{17}$ We obtained similar results when we replaced this measure with the number of months of exposure after birth.
} 
dummies for the duration of exposure to the conflict. This specification yields impact estimates that are slightly higher for older children and lower for younger ones, which is consistent with the idea that older children, who had longer exposure to the conflict than younger ones, accumulated a greater height deficit. (However, the difference is not statistically significant.) Next we focus on a continuous measure of exposure to the conflict (columns 5-6) and find that an additional month of exposure reduces height-for-age z-scores by $0.007-0.010$ s.d. on average (significant at the 5 percent level), depending on whether we control for province-specific trends. This effect translates into a height-for-age z-score loss of 0.11-0.15 s.d. for a one s.d. (15 months) increase in the duration of exposure to the war. ${ }^{18}$

The estimated coefficients on the triple interaction term with the female dummy are not statistically significantly different from zero in most specifications (columns 7-12). The estimated coefficient on "Conflict Region*Exposure 0-24 Months*Female" is positive and statistically significant at the 5 percent level (columns 9-10), suggesting that younger girls were affected by the conflict less than boys of the same age. This finding is not surprising in light of other anthropometric studies on sub-Saharan Africa. Unlike the research on child health and famines (Mu and Zhang, 2008) or natural disasters (Rose, 1999) in Asian countries, there is no consistent evidence of sex bias (against females) in child health studies for sub-Saharan Africa,

\footnotetext{
${ }^{18} \mathrm{We}$ also considered a definition of the war cohort that includes children exposed to the conflict in utero and in the first three years of life. This definition affects the assignment into categories only for children from the 2006 survey, whereby children aged 31-60 months at the start of the conflict are assigned to the control group. The estimated coefficient for $\beta_{1}$ is smaller than in our baseline regressions, likely because of adding to the control group children who were older than 37 months when the conflict started, and thus were also exposed to the conflict during their early childhood (Table A1).
} 
either during tranquil times or in the aftermath of shocks (Strauss, 1990; Alderman et al., 2006; Bundervoet et al., 2009; Akresh et al., 2011, 2012). ${ }^{19}$

Table 3 presents baseline specifications that have been augmented with additional control variables. In particular, we add child ethnicity and religion, characteristics of the household head (age, gender, education) and characteristics of the child's mother (age, education, marital status). These controls ensure that neither the factors we found to systematically differ for children in exposed vs. non-exposed households (Table 1) nor potential changes in sample composition during the period of analysis bias our results. F-tests for the joint significance of coefficients on the controls show that the only characteristic that does not systematically affect children's health is their ethnic background. In these regressions the average health impact of conflict is of similar magnitude to that in the specifications without controls. ${ }^{20}$

\section{III.2. Robustness Checks}

\section{III.2.1. Alternative Baseline Cohort}

It is possible that certain pre-conflict events may have affected the health of our baseline cohort, possibly confounding our main results. One such event is a military coup that led to a change in government in Côte d'Ivoire on December 26, 1999. The coup had a significant impact on the Ivorian economy, triggering an economic downturn. In its aftermath, private investment collapsed, public investment projects were postponed, social spending was cut back, and migrant

\footnotetext{
${ }^{19}$ Evidence of sex bias is more common in the context of shocks other than conflict. Akresh et al. (2011) and Cogneau and Jedwab (2012) document a stronger negative health impact on young girls in the case of crop failure in rural Burundi and a drop in cocoa prices in Côte d'Ivoire.

${ }^{20}$ We also estimated the baseline regressions allowing for differential trends in cohort health across rural vs. urban locations. The results (not reported) largely held up.
} 
workers fled following ethnic clashes in the south (Doré et al., 2003). From 1998 to 2002, the national poverty rate rose by five percentage points to almost 40 percent.

It is possible that children born after December 1999 experienced a decline in their wellbeing as the crisis unfolded. Thus, children born between January 2000 and August 2002 in the pre-war survey may constitute a poor baseline group to study the impact of the 2002-2007 civil conflict. ${ }^{21}$ Furthermore, children born during the same period and surveyed in 2006 could also be a poor treatment group as they were exposed to two large shocks-the coup and the conflict. As a robustness check, we exclude from the sample children from the 2002 and 2006 surveys who were born between January 2000 and August 2002, the month before the civil conflict erupted. Therefore, our new control group includes only children born before the coup and children born after the conflict started who lived outside conflict regions.

The results (Table 4) show that children born during the 2002-2007 conflict had significantly worse health compared to the new control group. Notably, the coefficient estimates on the interaction terms between the conflict exposure variables and "War Cohort" are at least twice as large compared to the baseline results (Tables 2-3). Our earlier results could thus be interpreted as conservative estimates of the impact of the Ivorian conflict on children's health.

\section{III.2.2. Results across Sub-samples}

We explore heterogeneity in the baseline results by separating children from different types of households and by gender. In Table 5 we present estimates for children from poor and non-poor households, girls vs. boys, rural vs. urban areas, and for children from households headed by

\footnotetext{
${ }^{21}$ The December 26, 1999 military coup led to a sharp drop in the economic performance and increased political instability, making it possible that children born before December 1999 also experienced a decline in health. We assume that any such impact was experienced uniformly across the country.
} 
individuals with some education and without any education. Columns 1-2 report results of the baseline regression models by poverty status. ${ }^{22}$ Poor households are identified using an assets index that refers to the quality of the dwelling and access to the grid and utilities. ${ }^{23} \mathrm{We}$ find that children exposed to the war were negatively impacted in both poor and non-poor households, losing on average 0.516 and 0.382 s.d. respectively relative to the reference population. ${ }^{24}$

When we split the sample into boys and girls (columns 3-4), we find that both girls and boys in the war cohort who lived in conflict regions suffered important health setbacks compared to same-age children outside conflict regions. Comparing these results with Table 2, we see that the coefficient estimated on the difference-in-differences term is larger in absolute value for girls, suggesting that young girls born or present during the conflict in more affected regions experienced a larger health setback than same-age girls in less affected regions than was the case for boys. (However, the estimated coefficients in the separate regressions for boys and girls are not statistically significantly different from each other.) When splitting the samples by area of

\footnotetext{
${ }^{22}$ Since the 2006 survey did not collect consumption data, we cannot construct consumption-based poverty measures that would be consistent across the three surveys. Instead, we use information on household assets available in all three surveys to construct an assets-based wealth index.

${ }^{23}$ The quality of the dwelling refers to whether the walls and floor are in cement or brick, and whether the roof is in metal, cement, or stone. Access to the grid refers to whether the household has electricity and a phone. Investment in utilities represents access to a toilet and using oil, natural gas, coal or electricity for cooking, rather than wood. The asset index is the first factor extracted using principal components analysis on the seven components and explains 47 percent of their joint variance. Poor households are those with asset index values lower than the average.

${ }^{24}$ To further investigate whether poverty is driving our results, we split the sample into three groups of children-in the poorest, middle, and richest households—based on the household assets index. We find a statistically significant negative impact of the conflict both for the children from the poorest and the middle wealth categories. This result suggests that extreme poverty cannot explain our results (Table A2).
} 
residence (rural/urban) or head's education (columns 5-8), we find that children from the war cohort who lived in conflict regions were impacted more in rural households and in households headed by individuals without education. Nevertheless, formal tests of the equality of the impact coefficients across sub-samples fail to reject the null of equality except for the rural-urban split.

\section{III.2.3. Selective Fertility and Mortality}

Two possible threats to the validity of our main findings are endogenous fertility and selective mortality. These may affect our results insofar as fertility decisions are systematically correlated with mothers' characteristics which may in turn affect child outcomes, or sex ratios. To address these issues, we undertake two exercises. First, we look at fertility decisions during the war by women of fertile age and compare them in and outside conflict regions. Second, we look for patterns in sex ratios for surviving children. For the first exercise we pool all women from the 2006 and 2008 surveys who were of fertile age and hence could have had a child during the conflict. ${ }^{25}$ We perform a set of regressions akin to Akresh et al. (2012) in which the dependent variables (for which we have consistent information across surveys) are women's age, education, and marital status. The covariates include dummy variables for residence in a conflict region, having a child during the war, and their interaction. The regression results (Table A3) confirm that while women who had a child during the conflict are younger, less educated, and more likely to be married, there are no systematic differences between the two groups across regions differentially affected by the conflict. However, these results are conditional on children surviving the war and staying in the same household with their mothers, as well as on mothers

\footnotetext{
${ }^{25}$ Since the surveys provide no or partial information on birth history, when it comes to women who had a child during the conflict, the analysis is confined to surveyed women with resident children and does not account for children who may have left the household or are deceased.
} 
surviving the war and not leaving Côte d'Ivoire. Next we examine patterns of selective attrition due to mortality or migration outside of Côte d'Ivoire by plotting sex ratios by year of birth for children with non-missing information on gender and location of current residence (Figure A3). While there are slightly more surviving boys than girls in most years during 1997-2007, there are no apparent differential trends across the two types of regions that could confound our results.

\section{III.2.4. Placebo Test}

Our analysis may be vulnerable to the criticism that the estimated impact of the conflict captures pre-existing differences between conflict and non-conflict regions. To alleviate this concern, our last robustness check is a placebo test that uses household- and individual-level data from the 1994 and the 1998/1999 Demographic and Health Surveys (DHS) for Côte d'Ivoire. Households included in these surveys could not have been affected by the war since the data were collected well before the 1999-2000 socio-economic crisis and the 2002-2007 conflict.

The results (Table 6) show that children in the placebo-conflict regions and the placebo war cohort did not have different height-for-age z-scores compared to children of similar age outside placebo-conflict regions and older children (columns 1-6). While the girls from placeboconflict regions and the placebo war cohort appear worse off in terms of health (columns 7-12), the difference-in-differences terms remain statistically insignificant regardless of the set of controls. Thus, the results suggest that pre-existing differences in child health across regions differentially involved in the conflict are unlikely to explain our baseline result.

\section{Household Victimization as a Conflict-Impact Mechanism}

\section{IV.1. Measures of Conflict-Induced Victimization}

We have so far documented a strong negative impact of the conflict as a covariate or a common shock on the health of young children, where all the households in regions in which conflict 
events were reported by ACLED were assumed to be equally exposed to these events. In this section we look beyond the covariate shock by focusing instead on idiosyncratic measures of exposure to the conflict. This strategy allows us to examine the role of household-level victimization as a potential channel through which the conflict can adversely impact child development. $^{26}$

To measure victimization, we rely on questions asked of household heads in the 2008 survey to assess the impact of the conflict on the population. ${ }^{27}$ These questions refer to a wide variety of war-related experiences. We group these into four categories: "economic losses" such as loss of income, employment and productive economic assets (farm and livestock); "health impairment" reflected in physical and mental ailments (conflict-related illness, anxiety, stress); different types of "displacement" (outright move of the entire household or of the household head, or going into hiding during the conflict); and "victim of violence" which refers to being a direct victim of conflict-related violence (that is, theft, rape, other sexual violence, physical wounds or other troubles), witnessing deaths in the household, or being forced into begging or prostitution. Table A4 lists the questions used to construct each index. T-tests for the differences in mean values of the components show that economic losses and displacement were more

\footnotetext{
${ }^{26}$ Related studies analyze the link between conflict-induced victimization and post-war outcomes such as political engagement in Sierra Leone (Bellows and Miguel, 2009) and social capital in Uganda (Rohner et al., 2011).

${ }^{27}$ There is a large literature on the relation between economic shocks and conflict, with a seminal study by Miguel et al. (2004) showing that economic shocks predict conflict. In our case, conflict-related victimization is a consequence of rather than a cause for the conflict since the data on war experiences were collected in the post-conflict survey with the goal to assess the effects of the conflict on households. This goal is reflected both in the title of the survey questionnaire ("Impact of the Conflict on the Population") and in the way in which the questions are phrased ("Because of the conflict,... did [...] happen?").
} 
prevalent in conflict regions, while households experienced relatively similar levels of health impairment inside and outside conflict regions.

For the regression analysis we construct household-level indices of victimization. We define both an overall victimization index calculated as the average of the indicator variables for affirmative answers to the questions, as well as separate indices for each of group of questions (economic losses, health impairment, displacement, and victim of violence) similarly defined as the averages of indicator variables for "yes" answers to the underlying questions.

We spatially examine the experience of war in Figure 2, which shows a victimization map based on the share of households that report at least one type of victimization. Darker shades represent provinces with a greater share of victimized households (i.e., responding yes to at least one question within each index). There is a fair degree of visual overlap with the ACLED-based conflict map (Figure 1), with more frequent reports of victimization in the western parts of the country, especially along the border with Liberia, and in Abidjan. The share of households reporting at least one level of victimization is positively related to conflict intensity proxied by the number of conflict events in the ACLED dataset (Table 7), with a correlation coefficient of 0.249 (statistically significant at the 10 percent level). For different types of victimization, the correlation coefficients with the ACLED measure are of similar magnitude. The province-level victimization indices are strongly correlated with one another, with the highest correlations found between health impairment and displacement on the one hand, and victim of violence on the other.

It is noteworthy that conflict-related victimization is also reported in the regions for which the ACLED dataset does not report any conflict event. There are several possible explanations for this. First, the effects of conflict can spill over from one community to another, 
as documented for instance in Montalvo and Reynal-Querol (2007). Second, the ACLED dataset may suffer from measurement error if certain communities or types of events (for instance, ethnic clashes) systematically receive more press coverage than others. Finally, our victimization variables are based on the experiences reported by the heads of households alone and the experiences of other household members may differ.

\section{IV.2. Selection into Victimization}

Before proceeding with the analysis of the war-impact mechanisms, we address a concern that is often raised in relation to self-reported victimization data, namely, that households that report victimization may belong to a select sample that was targeted for violence due to their characteristics. To determine the extent to which victimization status is correlated with observables, we regress each victimization index on a comprehensive set of characteristics of the heads of households, including ethnicity and religion, rural residence, age, marital status, education, and gender.

The results (Table 8) reported for the full sample and for non-migrant households, reveal systematic selection into victimization according to certain characteristics. The Southern Mandé, who live primarily in the western regions extensively affected by the conflict, systematically report more of all types of victimization than the Akan ethnic group (reference category). This observation is consistent with the visual examination of the conflict and victimization maps. Married household heads are also more likely to be victimized across all dimensions. These effects are statistically significant at the 1 percent level. In the full sample, Christian household heads are less likely to be victimized (significant at the 5 percent level). When it comes to the components of the victimization index, the ethnicity results are more mixed. Non-migrant naturalized Ivorians, who constitute only 0.3 percent of the dataset, are significantly less likely to 
report being direct victims of violence. We would have expected the opposite effect as foreigners were targeted during the conflict. However, since many ethnic groups native to Côte d'Ivoire are also found in neighboring countries, ethnic status may not be a good basis for classifying individuals as outsiders (Levinson, 1998). ${ }^{28}$ Further, older heads of households report more conflict-induced health effects (columns 5-6), more educated ones are more likely to report being victims of violence (columns 9-10), and married ones report more of all types of victimization other than health impairment.

In light of these findings, we allow for the possibility that household head's ethnicity and other characteristics may systematically be correlated with victimization (also suggested by the F-tests shown in Table 8) by including controls such as head's age, education, and child ethnicity (strongly correlated with household head's ethnicity) in most of our specifications (for a similar strategy, see Bellows and Miguel, 2009).

As the Ivorian conflict was characterized by high levels of migration and internal displacement (about 20 percent of the post-conflict sample), we also investigate whether households that moved out of conflict areas differ in their observables from those that did not, and whether they are more likely to report being victimized. When we compare household characteristics in conflict vs. non-conflict regions before and after the conflict, we find no systematic changes in the average household profile (Table A5). Further, households that migrated during the conflict, especially those displaced by the conflict, are statistically significantly more likely to report victimization than non-migrant households (Table A6). This

\footnotetext{
${ }^{28}$ McGovern (2011, pp. 71) points out that in western Côte d'Ivoire, "anyone not born in a village is technically a 'stranger'..." and that men moving 20 or 2,000 kilometers away from their native villages would be treated as foreigners in their new place of residence.
} 
result holds across alternative definitions of migration, and is conditional on poverty status, area of residence (rural/urban), household head characteristics, and province fixed effects. This finding suggests that there was negative selection into migration and positive selection into staying in conflict regions. Thus, the coefficient magnitudes we document below for the impact of household victimization for the full sample and the non-migrant sub-sample may be viewed as conservative estimates of the true impact of the conflict.

\section{IV.3. Identifying the Mechanisms}

To examine the role played by household victimization as a conflict-impact mechanism, we estimate several specifications. We begin by examining the cross-sectional impact of conflictinduced victimization on child health using solely the post-war (2008) survey. We estimate:

$$
H A Z_{i j t}=\alpha_{j}+\delta_{t}+\beta_{3}\left(\text { Victimized }_{i}\right)+\varepsilon_{i j t}
$$

The coefficient of interest, $\beta_{3}$, is an estimate of the direct effect of victimization on the health of children in the war cohort. Since non-migrant households are less likely to report victimization, we show the estimates separately for all households and for non-migrant households (Table 9). The coefficient estimates are remarkably stable regardless of the set of controls - for the child, the household head, or the child's mother-and whether or not we allow for pre-existing trends in cohort health $\left(\lambda_{j t}\right)$. The estimates for the full sample (Panel A, columns 1-6) suggest that children in households that experienced a higher degree of victimization have lower height-for-age z-scores (statistically significant in all but one specification): at the mean level of victimization ( 0.17 on a scale from 0 to 1$)$, an increase in the level of victimization by one s.d. (0.16) leads to a decline in the height-for-age $\mathrm{z}$-score by between 0.112 and 0.122 s.d. relative to the reference population. ${ }^{29} \mathrm{~A}$ test for the equality of coefficient estimates across

\footnotetext{
${ }^{29}$ Using the estimates in columns 4 and 2 respectively, we have $0.699 * 0.16=0.112$ and $0.761 * 0.16=0.122$.
} 
migrant and non-migrant households indicates that the effects are the same regardless of migration status. As the coefficient estimates are robust to the inclusion of additional controls, omitted variables that may be correlated with selection into victimization are unlikely to be driving our results.

In Table 10 we replace the overall "Victimized" index with its four components capturing forms of victimization such as economic losses, health impairment, displacement, and being a direct victim of violence. We find that the impact coefficients are mostly negative, suggesting that all forms of victimization hinder child health; however, only victimization in the form of economic losses has a statistically significant impact. Comparing the impact coefficients across migrant and non-migrant households, we note that once again there are no statistically significant differences by migration status.

We also assess how estimated causal impact of the covariate shock on child health, obtained in our baseline results, varies with the degree of conflict-related victimization reported by households. To do so, we go back to the baseline specification Eq. (1) and interact the difference-in-differences term "Conflict Region*War Cohort" with the "Victimized" variable. Since the latter is only available in the 2008 survey, this procedure amounts to estimating:

$$
H A Z_{i j t}=\alpha_{j}+\delta_{t}+\beta_{4}\left(\text { Conflict Region }_{\mathrm{j}} * \operatorname{Victimized}_{\mathrm{i}}\right)+\beta_{5}\left(\text { Victimized }_{\mathrm{i}}\right)+\varepsilon_{i j t}{ }^{30}
$$

on the pooled sample of children from the pre- and post-conflict surveys. By estimating Eq. (4) we ask whether the covariate shock has a differential impact on child health according to the degree of victimization experienced by the household in which the child resides. The coefficient

\footnotetext{
${ }^{30}$ As the data on the war experiences are available only in the 2008 survey, this specification implies that "Conflict Region*Victimized*War Cohort"="Conflict Region*Victimized" and "Victimized*War Cohort"= "Victimized".
} 
of interest is $\beta_{4}$. We control for rural and female dummies, and in some specifications we add gender interactions and province-specific trends $\left(\lambda_{j t}\right){ }^{31}$

The results (Table 11) suggest that the negative impact of the conflict on height is more pronounced for children living in victimized households. ${ }^{32}$ This finding holds when we use different sets of controls and for the non-migrant sub-sample (Panel A vs. Panel B). There is no evidence of a gender differential. ${ }^{33}$ In the full sample, the estimated coefficients on "Conflict region*Victimized" range between 1.134 and 2.475 s.d. (significant at least at the 10 percent level) in the regressions without gender interactions, and between 1.783 and 2.859 (significant at the 1 percent level) when we add gender interactions. ${ }^{34}$ As evidenced by the F-tests on the equality of "Conflict Region*Victimized" coefficient estimates in the migrant and non-migrant samples, conflict-induced victimization has an equally strong impact regardless of migration status. This observation suggests that migrant households were unable to mitigate the effects of conflict despite leaving conflict areas, possibly due to a breakdown in insurance mechanisms such as informal networks at the original place of residence (see, e.g., Kondylis, 2010).

\footnotetext{
${ }^{31}$ The estimated coefficients on the interaction terms with the female dummy "Conflict Region*Female", "War Cohort*Female," and "Victimized*Female" are jointly statistically insignificant and are not shown.

${ }^{32}$ We obtain similar results when we use an alternative definition of the victimization index based on principal components analysis (Table A7).

${ }^{33}$ For robustness we also used the alternative control group that excludes children born after January 1999 and thus exposed to the 1999-2000 socio-economic crisis, and obtained similar results (Table A8).

${ }^{34}$ When we estimate the same specifications but replace the overall "Victimized" index with the four sub-component indices (results not reported), the estimated coefficients on the interactions of interest are statistically insignificant, likely because of the high correlation among the indices.
} 


\section{Discussion and Conclusions}

We examined the effect of the 2002-2007 armed conflict in Côte d'Ivoire on children's heightfor-age z-scores using data from three household surveys collected before, during and after the conflict, coupled with information on the exact date and location of conflict events. Our results show that children aged 6-60 months who lived in conflict-affected areas suffered significant health setbacks compared to those in less affected areas. The negative impact is stronger for children exposed to the conflict for longer periods, for children in rural communities, and for those living in victimized households. In line with other studies of child health in sub-Saharan African countries, we did not find any evidence of sex bias.

The literature on the consequences of armed conflict has proposed several mechanisms through which war affects populations, including destruction of economic assets, lack of access to public infrastructure, and significant population movements. We were able to assess the role of distinct war impact mechanisms using unusually rich information on households' experiences of war from a post-conflict survey. We found that conflict-related household victimization hinders child health, especially in conflict regions. Furthermore, some types of victimization are more detrimental than others. Children in households that experienced economic losses through the destruction of productive assets (livestock) and properties (farm), loss of employment, and more generally a fall in household revenues, experienced large health setbacks, and the coefficients are statistically significant. Children in households headed by adults who suffered either physical or mental ailments due to the conflict, and who experienced direct violence and deaths in the family, also accumulated a stature deficit, but the coefficients are less precisely estimated. Across a wide range of empirical models, we found no difference in the stature deficit 
for children from migrant and non-migrant households, suggesting that although pervasive, ${ }^{35}$ internal displacement did not play an additional negative role in the Ivorian context. Once again, the results are valid for the surviving households that remained in the country, and may not apply to those that migrated to other countries. Taken together, these findings represent direct evidence for some of the adverse effects of armed conflict hypothesized in the literature.

Naturally, the conflict impact mechanisms identified in our study are not exhaustive. Recent case studies by Fürst et al. (2009) and Betsi et al. (2006) complement our findings by documenting the decline in the state of the health infrastructure during the conflict. Based on household interviews, Fürst et al. (2009) find a significant deterioration in access to health services and a higher incidence of tropical diseases in the conflict-affected western region of Man in 2003. Betsi et al. (2006) report a large reduction in the number of health facilities and personnel (especially doctors) in the central, northern, and western regions of Côte d'Ivoire around the same time. In the first two years of the conflict, rebel-held regions lost between 75-90 percent of health personnel and 72-90 percent of health facilities due to looting or destruction. Given the relatively poor pre-conflict stock of health infrastructure, conflict-induced losses of health workers and facilities likely had a major impact on the health of children, both directly and through their impact on the adults in the household. In addition, the deterioration of public

\footnotetext{
${ }^{35}$ Some reports indicate that by late-2002 the number of war-affected people had reached between 2.7 million (including the internally displaced) and four million (including evacuees and refugees to neighboring countries) (UNOCHA, 2003). Other sources indicate that in the first ten months more than half a million people were displaced (UNICEF, 2003). Martone (2003) provides comparable estimates.
} 
health infrastructure at a time when it was needed most may have compounded existing health deficiencies. $^{36}$

By documenting the role played by conflict impact mechanisms in explaining changes in child health, we can suggest policies that could mitigate the adverse effects of armed conflict. As economic losses were the most relevant channel associated with the decline in child health in the context of Côte d'Ivoire, interventions that target conflict regions, for instance, through cash transfers and employment programs aimed at rebuilding household assets, rehabilitating basic social services, and assisting the return of the displaced, can help alleviate the effects of the conflict and restore economic well-being.

As knowledge on the consequences of large negative shocks on child development accumulates, more research into households' coping strategies and best public policy responses is needed. In the context of armed conflict, Arcand and Wouabe (2009) study the effectiveness of a social spending program during the Angolan war. They find that the benefits of the program, namely higher child stature and household consumption, are either constant or increase with conflict intensity, which suggests that even relatively small investments in a post-conflict environment can have a large impact on well-being. When it comes to directly investing in child health, programs that focus on the local production of nutritional supplements (e.g., fortified peanut paste) as in Haiti (Rice, 2010), can create jobs in addition to providing access to locallyproduced nutritional supplements for malnourished children.

\footnotetext{
${ }^{36}$ To test this idea, data on pre- and post-conflict stock and quality of health infrastructure at the province or community level would be required.
} 


\section{References}

Agüero, J. M. and A. Deolalikar, 2012, "Late bloomers? Identifying critical periods in human capital accumulation. Evidence from the Rwanda Genocide," unpublished manuscript, University of California, Riverside.

Akresh, R., Verwimp, P. and T. Bundervoet, 2011, "Civil war, crop failure, and child stunting in Rwanda," Economic Development and Cultural Change, Vol. 59, Issue 4, pp. 777-810.

Akresh, R.; L. Lucchetti; H. Thirumurthy, 2012, "Wars and child health: Evidence from the Eritrean-Ethiopian conflict," Journal of Development Economics, Vol. 99, pp. 330-40.

Akbulut-Yuksel, M., 2009, "Children of war: The long-run effects of large-scale physical destruction and warfare on children," IZA Discussion Paper No. 4407.

Alderman, H., J. Hoddinott and B. Kinsey, 2006, "Long term consequences of early childhood malnutrition," Oxford Economic Papers, 2006, Vol. 58, Issue 3, pp. 450-474.

Almond, D. and J. Currie, 2011, "Human capital development before age five," Handbook of Labor Economics, Vol. 4, Part B, pp. 1315-1486.

Altonji, J. G., Elder, T.E., and C. R. Taber, 2005, "Selection on observed and unobserved variables: Assessing the effectiveness of Catholic schools," Journal of Political Economy, Vol. 113, Issue 1, pp. 151-184.

Arcand, J.-L. and E. D. Wouabe, 2009, "How effective are social programs during conflicts? Evidence from the civil war in Angola," unpublished manuscript. The Graduate Institute, Geneva.

Baez, J. E., 2011, "Civil wars beyond their borders: The human capital and health consequences of hosting refugees," Journal of Development Economics, Vol. 96, Issue 2, pp. 391-408.

Bellows, J. and E. Miguel, 2009, "War and collective action in Sierra Leone," Journal of Public Economics, Vol. 93, pp. 1144-1157.

Betsi, N. A., Koudou, B.G., Cisse, G., Tschannen, A. B., Pignol, A. M., Ouattara, Y., Madougou, Z., Tanner, M. and J. Utzinger, 2006, "Effect of an armed conflict on human resources and health systems in Côte d'Ivoire: Prevention of and care for people with HIV/Aids," Aids CarePsychological and Socio-Medical Aspects of Aids/HIV, Vol. 18, Issue 4, pp. 356-65.

Blattman, C. and J. Annan, 2010, "The consequences of child soldiering," Review of Economics and Statistics, Vol. 92, Issue 4, pp. 882-98.

Brakman, S., H. Garretsen, and M. Schramm, 2004, "The strategic bombing of German cities during World War II and its impact on city growth," Journal of Economic Geography, Vol. 4, Issue 2, pp. 201-218.

Bundervoet, T., Verwimp, P. and R. Akresh, 2009, "Health and civil war in rural Burundi," Journal of Human Resources, Vol. 44, Issue 2, pp. 536-563.

Chamarbagwala, R. and H. E. Morán., 2011, "The human capital consequences of civil war: Evidence from Guatemala." Journal of Development Economics, Vol. 94, Issue 1, pp. 41-61.

Chelpi-den-Hamer, M., 2011, "Militarized youths in Western Côte d'Ivoire: Local processes of mobilization, demobilization and related humanitarian interventions (2002-2007)," African Studies Collection, Vol. 36, African Studies Center: Leiden.

Cogneau, D. and R. Jedwab, 2012, "Commodity price shocks and child outcomes: The 1990 cocoa crisis in Côte d'Ivoire," Economic Development and Cultural Change, Vol. 60, Issue 3, pp. 507-534. 
Cogneau, D. and L. Rouanet, 2009, "Living conditions in Côte d'Ivoire, Ghana, and Western Africa 1925-1985: What do survey data on height stature tell us?" DIAL Working Paper No. DT/2009/12.

Currie, J., 2009, "Healthy, wealthy, and wise: Socioeconomic status, poor health in childhood, and human capital development," Journal of Economic Literature, Vol. 47, Issue 1, pp. 87122.

Davis, D. and D. Weinstein, 2002, "Bones, bombs, and break points: The geography of economic activity," American Economic Review, Vol. 92, Issue 5, pp. 1269-1289.

de Walque, D., 2011, "Conflicts, epidemics, and orphanhood: The impact of extreme events on the health and educational achievements of children," in (ed.) Alderman, H., No Small Matter: The Impact of Poverty, Shocks, and Human Capital Investments in Early Childhood Development, Human Development Perspectives (Washington, DC: The International Bank for Reconstruction and Development and The World Bank Group).

Domingues, P., 2011, "Health and conflict: Evidence from Mozambique," in Raul Caruso (eds.), Ethnic Conflict, Civil War and Cost of Conflict (Contributions to Conflict Management, Peace Economics and Development, Vol. 17), Emerald Group Publishing Limited, pp. 141169.

Doré, O., Benoit, A., and D. Engmann, 2003, "Regional impact of Côte d'Ivoire's 1999-2000 sociopolitical crisis: An assessment," IMF Working Paper No. 03/85 (Washington, DC: International Monetary Fund).

Fürst, T., Raso, G., Acka, C. A., Tschannen, A. B., N'Goran, E. K. and J. Utzinger, 2009, "Dynamics of socioeconomic risk factors for neglected tropical diseases and malaria in an armed conflict," PLoS Neglected Tropical Diseases, Vol. 3, Issue 9, pp. 1-10.

Glewwe, P., Jacoby, H. G. and E. M. King, 2001, "Early childhood nutrition and academic achievement: A longitudinal analysis," Journal of Public Economics, Vol. 81, Issue 3, pp. 345-368.

HLSS-2008, "Enquête sur le Niveau de Vie des Ménages de Côte d'Ivoire (ENV)," National Statistical Institute and Ministry of Planning and Development of Côte d'Ivoire.

HLSS-2002, "Enquête sur le Niveau de Vie des Ménages de Côte d'Ivoire (ENV)," National Statistical Institute and Ministry of Planning and Development of Côte d'Ivoire.

Kondylis, F., 2010, "Conflict displacement and labor market outcomes in post-war Bosnia and Herzegovina," Journal of Development Economics, Vol. 93, Issue 2, pp. 235-248.

Kuhlman, T., 2007, "Responding to protracted refugee situations: A case study of Liberian refugees in Côte d'Ivoire," UNHCR Evaluation and Policy Analysis Unit, EPAU2002/07, July (Geneva: United Nations High Commissioner for Refugees).

Leon, G., forthcoming, "Civil conflict and human capital accumulation: The long-term effects of political violence in Peru," Journal of Human Resources.

Levinson, D., 1998, Ethnic Groups Worldwide: A Ready Reference Handbook, ORYX Press, 1998.

Mansour, H. and D. I. Rees, 2012, "Armed conflict and birth weight: Evidence from the Al-Aqsa Intifada," Journal of Development Economics, Vol. 99, Issue 1, pp. 190-99.

Martone, G., 2003, "The crisis in West Africa," American Journal of Nursing, Vol. 103, pp. 3240.

Martorell, R. and J. Habicht, 1986, "Growth in early childhood in developing countries," in F. Falkner and J. Tanner, eds. Human Growth: A Comprehensive Treatise, Vol. 3, 2nd edition, Plenum Press: New York. 
Marshall, M. G., 2010, "Major Episodes of Political Violence (MEVP) and Conflict Regions, 1946-2008," Center for Systemic Peace. Available on: http://www.systemicpeace.org/inscr/inscr.htm (accessed November 27, 2011).

MICS3-2006, "Enquête par Grappe à Indicateurs Multiples," National Statistical Institute and Ministry of Planning and Development of Côte d'Ivoire, and UNICEF.

Miguel, E. and G. Roland, 2011, "The long-run impact of bombing Vietnam," Journal of Development Economics, Vol. 96, Issue 1, pp. 1-15.

Minoiu, C. and O. Shemyakina, 2012, "Child health and conflict in Côte d'Ivoire," American Economic Review Papers \& Proceedings, Vol. 102, Issue 3, pp. 294-299.

Mitchell, M. I., 2011, "Insights from the cocoa regions in Côte d'Ivoire and Ghana: Rethinking the migration-conflict nexus," African Studies Review, Vol. 54, Issue 2, pp. 123-144.

Montalvo, J. G. and M. Reynal-Querol, 2007, "Fighting against Malaria: Prevent Wars While Waiting for The "Miraculous" Vaccine," The Review of Economics and Statistics, Vol. 89, Issue 1, pp. 165-77.

Mu, R. and X. Zhang, 2008, "Gender Difference in the Long-Term Impact of Famine," IFPRI Discussion Paper No. 760 (Washington, DC: International Food and Policy Research Institute).

Raleigh, C., Linke, A., Hegre, H. and J. Karlsen, 2010, "Introducing ACLED-Armed Conflict Location and Event Data," Journal of Peace Research, Vol. 47, Issue 5, pp. 1-10.

Rice, A., 2010, "The peanut solution," The New York Times. New York: The New York Times, page MM36, September 5.

Rohner, D., Thoenig, M., and F. Zilibotti, 2011, "Seeds of Distrust: Conflict in Uganda," Department of Economics and Center for Institutions, Policy and Culture in the Development Process Working Paper No. 417 (Zurich: University of Zurich).

Rose, E., 1999, "Consumption smoothing and excess female mortality in rural India," The Review of Economics and Statistics, Vol. 81, Issue 1, pp. 41-49.

Sany, J., 2010, "USIP special report," United States Institute of Peace. Available on: http://www.usip.org/files/resources/SR235Sany_final_lowres-1.pdf (accessed: November 27, 2011).

Shemyakina, O., 2011, "The effect of armed conflict on accumulation of schooling: Results from Tajikistan," Journal of Development Economics, Vol. 95, Issue 2, pp. 186-200.

Strauss, J. and D. Thomas, 1998, "Health, nutrition, and economic development," Journal of Economic Literature, Vol. 36, Issue 2, pp. 766-817.

Strauss, J., 1990, "Households, communities, and preschool children's nutrition outcomes: Evidence from rural Côte d'Ivoire," Economic Development and Cultural Change, Vol. 38, Issue 2, pp. 231-261.

Swee, E.L., 2011, "On war and schooling attainment: The case of Bosnia and Herzegovina," unpublished manuscript, University of Melbourne.

Thomas, D., V. Lavy and J. Strauss, 1996, "Public policy and anthropometric outcomes in Côte d'Ivoire," Journal of Public Economics, Vol. 61, Issue 2, pp. 155-192.

UCDP/PRIO, 2009. UCDP/PRIO Armed Conflict Dataset Codebook Version 4-2009. Uppsala and Oslo: Uppsala Conflict Data Program (UCDP) and International Peace Research Institute (PRIO).

UK Home Office, 2007, "UK Border Agency-Ivory Coast Operational Guidance Note v4.0 2," August, available on http://www.unhcr.org/refworld/pdfid/4602932c2.pdf (accessed: November 9, 2011). 
UNICEF, 2003, "Côte d'Ivoire sub-regional crisis donor update," 15 September, available on http://reliefweb.int/node/117935 (accessed November 1, 2011).

UNOCHA, 2003a, "Crisis in Côte d'Ivoire situation report no. 17." December 12, available on http://reliefweb.int/node/139242 (accessed: November 29, 2011).

UNOCHA, 2003b, "Fighting near the Liberian capital drives thousands into bush," February 8, available on http://reliefweb.int/node/119067 (accessed: November 29, 2011).

UNOCHA, 2004, "Fighting in Côte d'Ivoire jeopardizes humanitarian aid," November 4, available on http://reliefweb.int/node/157760 (accessed: November 22, 2011).

UNOCHA, 2006a, "Côte d'Ivoire: Five dead in clashes with UN peacekeepers in Wild West," January 18, available on www.irinnews.org/report.asp?ReportID=51196 (accessed:

November 22, 2011).

UNOCHA, 2006b, "Côte d'Ivoire: UN staff being evacuated as sanctions loom," January 27, available on http://www.irinnews.org/printreport.aspx? reportid=57960 (accessed: November 22, 2011).

Verwimp, P., 2012, "Undernutrition, subsequent risk of mortality and civil war in Burundi," Economics and Human Biology, Vol. 10, Issue 3, pp. 221-31. 


\section{$\underline{\text { Data Appendix }}$}

\section{Our data sources are: ${ }^{37}$}

- Household surveys:

○ HLSS-2002. "Enquête sur le Niveau de Vie des Ménages de Côte d'Ivoire." (Household Living Standards Survey), National Statistical Institute, Ministry of Planning and Development of Côte d'Ivoire, World Bank and European Union.

o HLSS-2008. "Enquête sur le Niveau de Vie des Ménages de Côte d'Ivoire." (Household Living Standards Survey), National Statistical Institute, Ministry of Planning and Development of Côte d'Ivoire, World Bank and European Union.

- MICS3-2006. "Enquête par Grappe à Indicateurs Multiples." (Multiple Indicator Cluster Survey), National Statistical Institute, Ministry of Planning and Development of Côte d'Ivoire, and UNICEF. Available on: http://www.childinfo.org/mics3_surveys.html

○ DHS-1994 and DHS-1998/99. Demographic and Health Surveys for Côte d'Ivoire. Available on: http://www.measuredhs.com/

- Armed Conflict Location and Event Data (ACLED) from http://www.acleddata.com/ (see http://www.acleddata.com/archived-data/ for datasets), Raleigh et al. (2010).

\section{Calculating height-for-age z-scores}

Height-for-age z-scores for children in the 2002 and 2008 surveys are calculated using WHO Multicenter Growth reference datasets and the WHO Anthro (version 3.2.2 January 2011) STATA routines (http://www.who.int/childgrowth/software/en/). Observations with biologically implausible z-scores (that is, more than 6 standard deviations away from the international reference population) are dropped from the analysis. The MICS3-2006 survey includes alreadycalculated height-for-age z-scores using WHO reference datasets. The total number of children with biologically plausible height-for-age z-scores is 15,421 (5,885 in the 2002 survey, 7,232 in the 2005 survey, and 2,304 in the 2008 survey).

\section{Defining non-migrant households}

HLSS-2002. Non-migrant households are defined as those that lived in their current location (as of the interview date in fall 2002) since December 1993. The December 1993 cutoff was chosen because it marks the death of Ivorian president Félix Houphouët-Boigny.

HLSS-2008. Non-migrant households are defined as households that had lived in their current location since August of 2002, that is, before the start of the 2002-2007 armed conflict. MICS3-2006. Migration data is unavailable.

\section{Defining rural households}

Neither survey provides information on rural/urban sector of (current) residence. We create an indicator variable for children in rural residence based on children's recorded place of birth and

\footnotetext{
37 The surveys were undertaken by the National Institute of Statistics in Côte d'Ivoire in collaboration with the World Bank, European Union and UNICEF respectively. For information on how the height data was cleaned, see the online appendix of Minoiu and Shemyakina (2012).
} 
migration history. Children from non-migrant households are assigned their sector of birth. For 23 children in the 2008 survey for whom this information is missing, we use instead the household head's sector of birth as long as the household head has been in the household's current location since the child's birth, and it is a non-migrant household (that is, the child was born in that location). For regressions examining selection into victimization, the household head's sector of birth is imputed as the sector of residence if the household head has been in their current location since birth.

\section{Maps}

The conflict event map was created by manually matching conflict event locations from ACLED with children's location in the household surveys. ACLED locations are either provinces, in which case the merging is automatic, or villages and towns, in which case we match them to their respective province (using information from http://www.maplandia.com/search/). The maps (Figures 1,2) were created using the "spmap" STATA routine

(http://www.stata.com/support/faqs/graphics/spmap.html). The Atlas for Côte d'Ivoire with GIS information is from Dynamic Atlas (http://psugeo.org/Africa/Tools.htm). 
Figure 1. Map of Conflict Events in Côte d'Ivoire, September 2002-November 2007

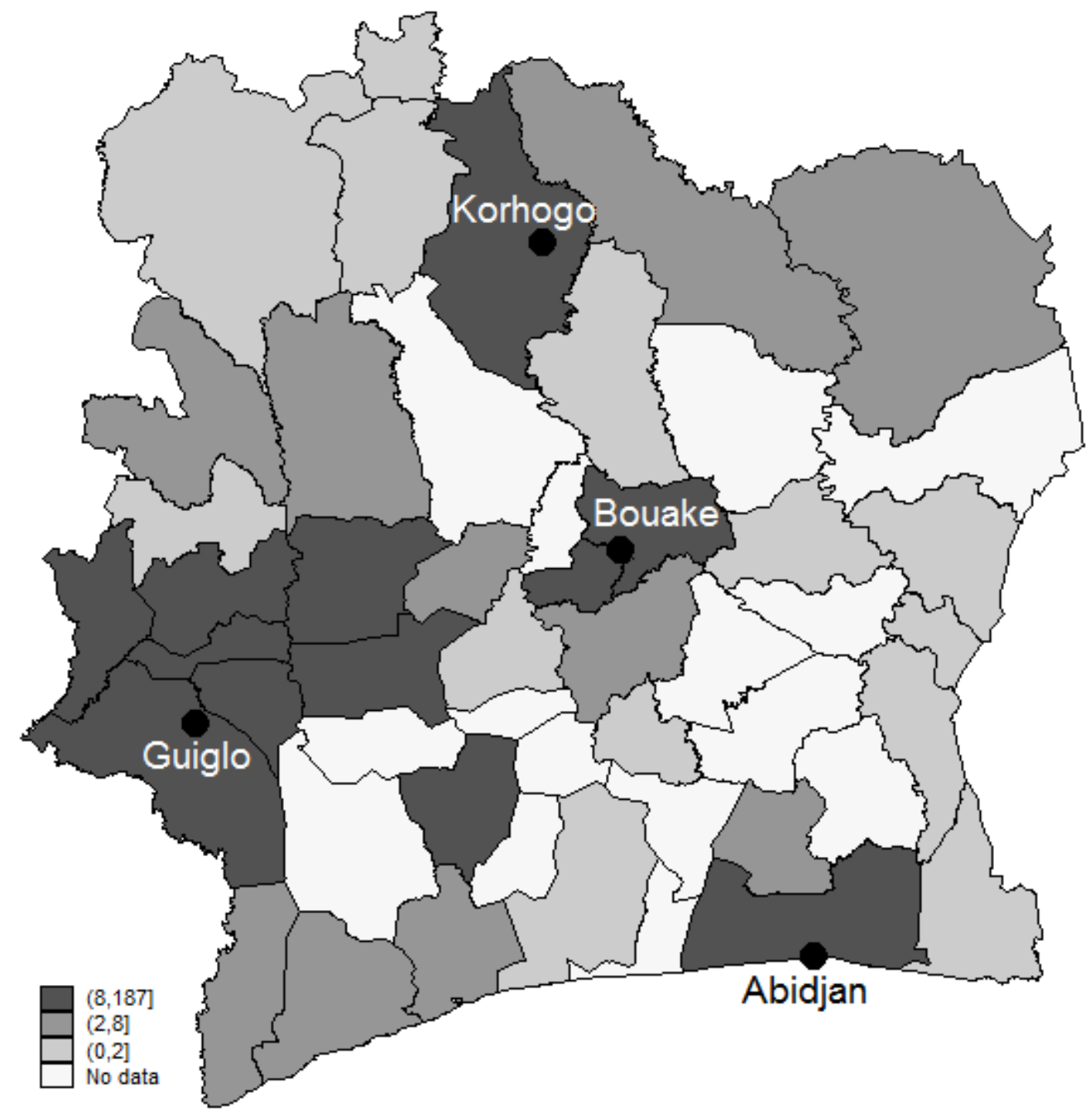

Notes: Shaded areas represent conflict regions. Darker shades indicate a greater number of conflict events reported in the ACLED dataset. In the legend, the "No data" category stands for no reported incidents in the dataset and is treated as zero exposure to conflict in the analysis. The category $(8,187]$ includes 12 provinces, some of which had relatively low-intensity conflict (between 10 and 30 events) and some with relatively high-intensity conflict, such as Abidjan in the south (187 events), Bouaké in the center (62 events), and the province of Guiglo in the west (48 events). The location of the cities on the map is approximate. Data sources: Based on ACLED dataset, Raleigh et al. (2010). 
Figure 2. Map of Conflict-related Household Victimization in Côte d'Ivoire (Post-conflict survey)

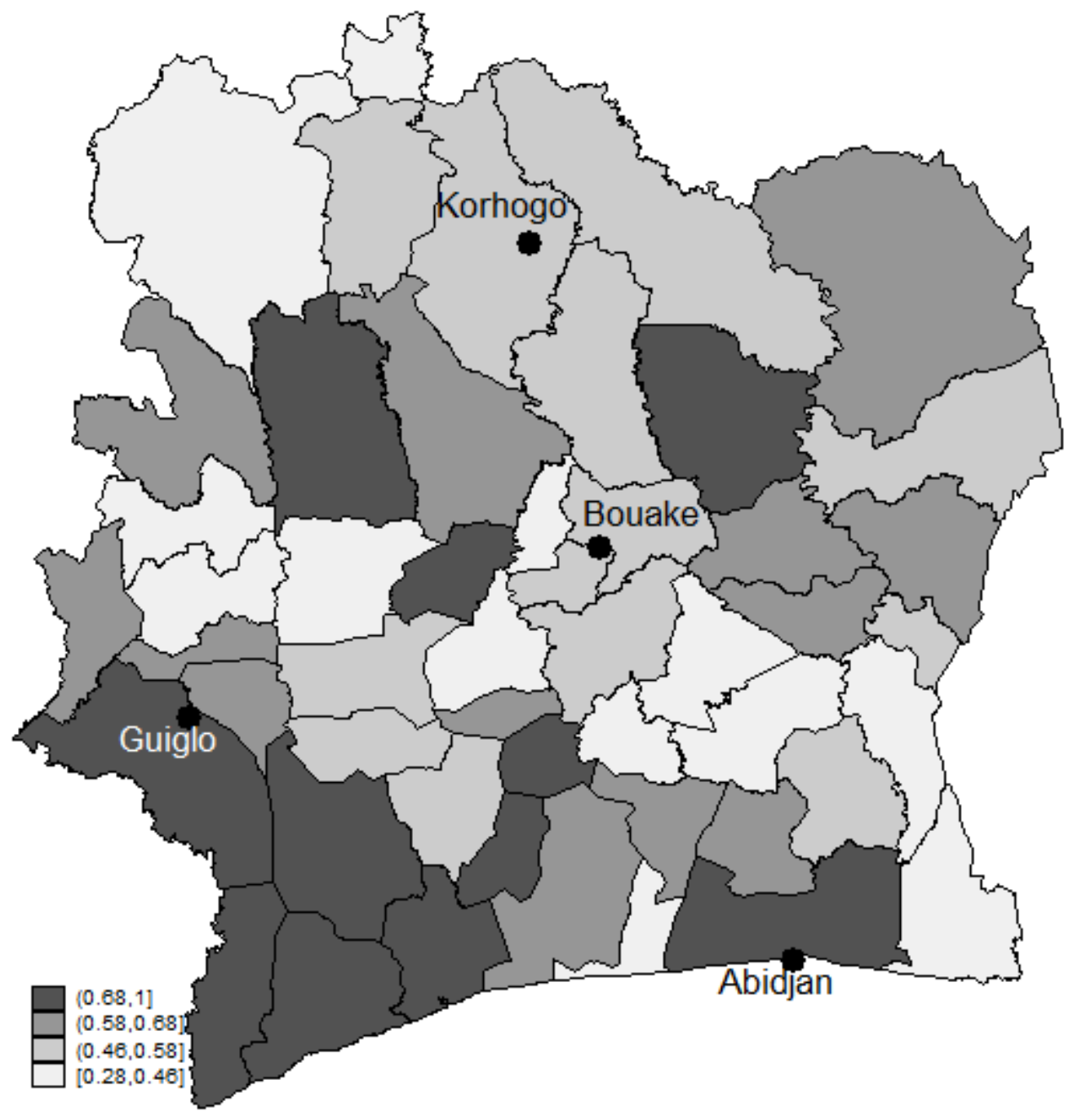

Notes: Shaded areas represent regions where conflict-induced victimization was reported. Darker shades indicate a greater share of households reporting at least one level of victimization (one 'yes' answer to the questions underlying each index). The location of the cities on the map is approximate. Data source: Based on the 2008 Côte d'Ivoire HLSS. 


\section{Table 1. Summary Statistics}

\begin{tabular}{|c|c|c|c|c|c|c|}
\hline & [1] & [2] & [3] & [4] & [5] & [6] \\
\hline & Obs. & Full & Non-migrants & $\begin{array}{l}\text { Conflict } \\
\text { Region }\end{array}$ & $\begin{array}{c}\text { Non-Conflict } \\
\text { Region }\end{array}$ & $\begin{array}{c}\text { Difference in } \\
\text { Means } \\
{[4]-[5]}\end{array}$ \\
\hline \multicolumn{7}{|l|}{ Child Variables } \\
\hline Height-for-age z-score (2002) & 5,885 & -1.93 & -1.97 & -1.88 & -2.01 & $0.13 * *$ \\
\hline Height-for-age z-score (2006) & 7,232 & -1.52 & - & -1.49 & -1.59 & $0.09 * * *$ \\
\hline Height-for-age z-score (2008) & 2,304 & -1.55 & -1.61 & -1.52 & -1.61 & 0.10 \\
\hline Height-for-age z-score (pooled) & 15,421 & -1.93 & -1.97 & -1.88 & -2.01 & $0.13 * * *$ \\
\hline Age in months (2002) & 5,885 & 34.14 & 34.58 & 34.04 & 34.84 & -0.81 \\
\hline Age in months (2006) & 7,232 & 31.31 & - & 31.25 & 31.45 & -0.19 \\
\hline Age in months (2008) & 2,304 & 37.12 & 37.43 & 37.04 & 37.30 & -0.26 \\
\hline Age in months (pooled) & 15,421 & 34.13 & 34.58 & 34.03 & 34.83 & -0.80 \\
\hline Child is female (pooled) & 15,421 & 0.50 & 0.51 & 0.50 & 0.51 & -0.01 \\
\hline Child resides in rural household (pooled) & 15,265 & 0.56 & 0.61 & 0.52 & 0.65 & $-0.13 * * *$ \\
\hline Child resides in pre-conflict poor household (2002) & 5,885 & 0.46 & 0.51 & 0.49 & 0.41 & $0.08 * * *$ \\
\hline Child resides in victimized household (2008) & 2,304 & 0.86 & 0.87 & 0.87 & 0.84 & 0.18 \\
\hline Months of exposure to the conflict (2006) & 7,232 & 39.34 & - & 39.30 & 39.44 & -0.15 \\
\hline Months of exposure to the conflict (2008) & 2,304 & 30.25 & 30.54 & 30.28 & 30.19 & 0.09 \\
\hline Months of exposure to the conflict (pooled) & 9,536 & 37.08 & 30.54 & 37.05 & 37.16 & -0.11 \\
\hline Exposure 0-24 months (pooled) & 9,536 & 0.24 & - & 0.24 & 0.24 & -0.01 \\
\hline Exposure at least 25 months (pooled) & 9,536 & 0.76 & - & 0.76 & 0.76 & 0.01 \\
\hline \multicolumn{7}{|l|}{ Ethnicity (pooled) } \\
\hline Akan & 14,015 & 0.29 & 0.29 & 0.22 & 0.44 & $-0.22 * * *$ \\
\hline Northern Mande & 14,015 & 0.13 & 0.14 & 0.15 & 0.09 & $0.06 * * *$ \\
\hline Southern Mande & 14,015 & 0.13 & 0.14 & 0.16 & 0.05 & $0.11 * * *$ \\
\hline Krou & 14,015 & 0.14 & 0.13 & 0.14 & 0.12 & $0.02 * * *$ \\
\hline Voltaique/Gur & 14,015 & 0.12 & 0.12 & 0.15 & 0.07 & $0.08 * * *$ \\
\hline Naturalized Ivorian & 14,015 & 0.003 & 0.004 & 0.004 & 0.002 & 0.001 \\
\hline Non-Ivorian & 14,015 & 0.19 & 0.17 & 0.18 & 0.23 & $-0.05 * * *$ \\
\hline \multicolumn{7}{|l|}{ Religion (pooled) } \\
\hline Muslim & 15,381 & 0.35 & 0.36 & 0.37 & 0.30 & $0.07 * * *$ \\
\hline Christian & 15,381 & 0.37 & 0.33 & 0.33 & 0.46 & $-0.13 * * *$ \\
\hline Other & 15,381 & 0.28 & 0.32 & 0.30 & 0.24 & $0.06 * * *$ \\
\hline \multicolumn{7}{|l|}{ Head of the Household (pooled) } \\
\hline Head's age & 15,388 & 43.80 & 46.12 & 43.98 & 43.25 & 0.73 \\
\hline Head's education & 15,391 & 0.44 & 0.39 & 0.45 & 0.42 & 0.03 \\
\hline Head is male & 15,421 & 0.86 & 0.86 & 0.87 & 0.86 & 0.00 \\
\hline \multicolumn{7}{|l|}{ Child's Mother (pooled) } \\
\hline Mother's age & 13,746 & 29.76 & 30.33 & 29.90 & 29.58 & 0.32 \\
\hline Mother's education & 14,648 & 0.32 & 0.28 & 0.32 & 0.31 & 0.01 \\
\hline Mother is married & 13,749 & 0.83 & 0.82 & 0.83 & 0.84 & $0.00 * * *$ \\
\hline
\end{tabular}

Notes: * significant at 10\%; ** significant at 5\%; *** significant at 1\%. In the 2002 survey, non-migrant households have lived in their current location (as of interview date) since December 1993; in the 2008 survey they are households in their current location since before the start of the war. Information on households' migration status and household heads' marital status is unavailable in the 2006 dataset. Education of the head of household and child's mother is proxied by an indicator variable for having attended school. The pre-crisis poverty rate is based on the national (consumption) poverty line. Estimates are weighted by inverse sampling probability. Data sources: 2002 and 2008 Côte d'Ivoire HLSS, 2006 Côte d'Ivoire MICS3, and Raleigh et al. (2010). 
Table 2. Impact of Conflict on Child Health. Baseline Regressions.

[1] [2] [3]

[4]

[5]

[7]

(1)

\begin{tabular}{cc} 
& \\
\hline$-0.250 * *$ & $-0.414 * *$ \\
$(0.094)$ & $(0.149)$
\end{tabular}

Conflict region*War Cohort

Conflict region*War Cohort*Female

Conflict region*Exposure 0-24 months

Conflict region*Exposure at least 25 months

Conflict region*Exposure 0-24 months*Female

Conflict region*Exposure at least 25 months*Female

Conflict region*Exposure (no. of months)

Conflict region*Exposure (no. of months)*Female

Female

Rural household

Province-specific trends

Observations

R-squared

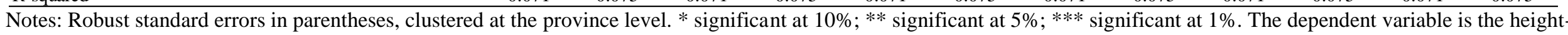

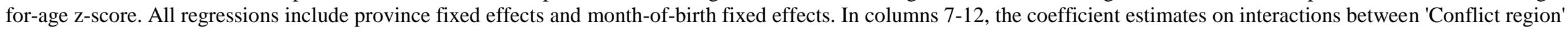

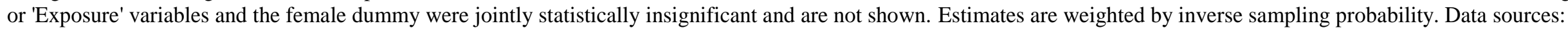
2002 and 2008 Côte d'Ivoire HLSS, 2006 Côte d'Ivoire MICS3, and Raleigh et al. (2010).
$-0.276 * * *-0.432 * * *$

$(0.077) \quad(0.134)$

$-0.014 \quad-0.031$

$(0.103) \quad(0.107)$

$\begin{array}{cc}-0.126 & -0.369 * * \\ (0.092) & (0.155) \\ -0.287 * * & -0.427 * * \\ (0.113) & (0.159)\end{array}$

$-0.296 * *-0.560 * * *$

$(0.124) \quad(0.166)$

$-0.283 * *-0.417 * *$

(0.101) (0.161)

$0.283 * * 0.332 * *$

$(0.108) \quad(0.133)$

$-0.075-0.087$

(0.080) (0.078)

(0.003) (0.004)

$\begin{array}{ccccccccccccc}0.216^{* * *} & 0.217 * * * & 0.216^{* * *} & 0.217 * * * & 0.216^{* * *} & 0.217 * * * & 0.136 & 0.137 & 0.137 & 0.137 & 0.137 & 0.137 \\ (0.061) & (0.060) & (0.061) & (0.060) & (0.061) & (0.060) & (0.120) & (0.121) & (0.120) & (0.121) & (0.120) & (0.121) \\ -0.485^{* * *} & -0.484 * * * & -0.485^{* * *} & -0.484 * * * & -0.485^{* * *} & -0.484 * * * & -0.475^{* * *} & -0.473 * * * & -0.475^{* * *} & -0.473 * * * & -0.475 * * * & -0.473^{* * *} \\ (0.092) & (0.094) & (0.092) & (0.094) & (0.092) & (0.094) & (0.083) & (0.085) & (0.083) & (0.085) & (0.083) & (0.085)\end{array}$

$-0.007 * * \quad-0.010^{* *}$ 
Table 3. Impact of Conflict on Child Health. Baseline Regressions with Additional Controls.

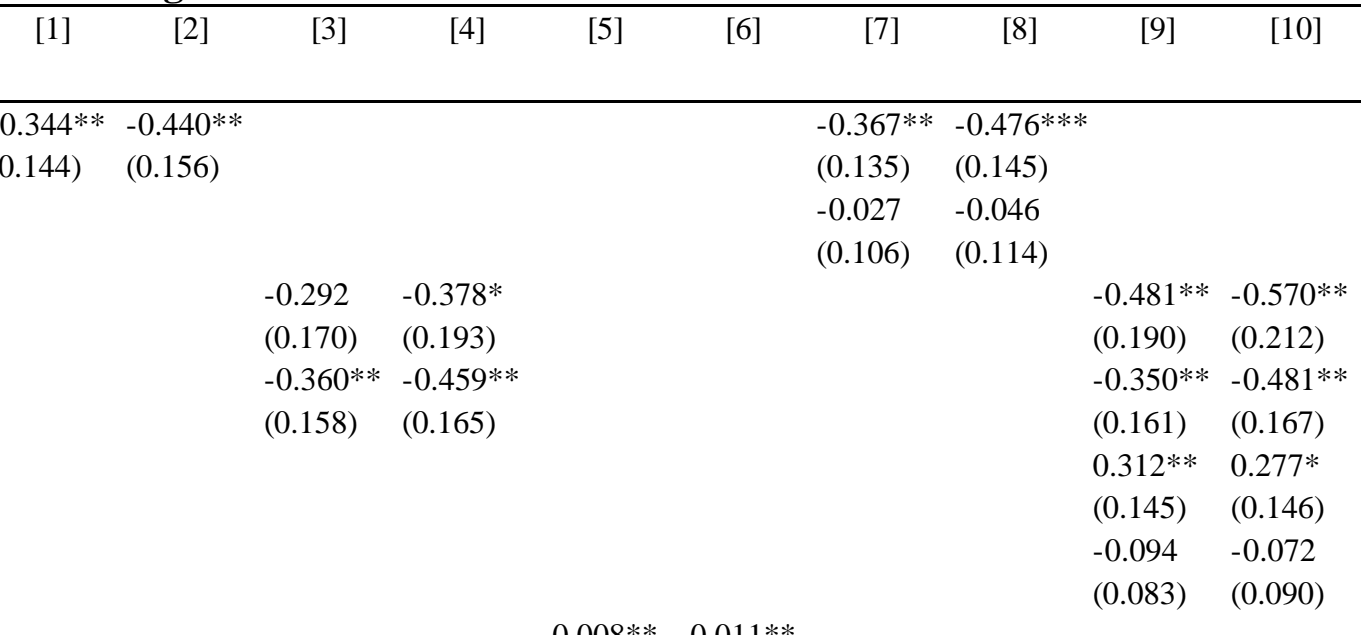

Conflict region*Exposure (no. of months)

$(0.004) \quad(0.004)$

Conflict region*Exposure (no. of months)*Female

Female

Rural household

Province-specific trends

Child controls

Household head controls

Mother controls

p-value F-test of zero effect of:

Child ethnicity

Child religion

Household head's characteristics

Mother's characteristics

Observations

$$
\begin{aligned}
& 0.2 \\
& (0.059 \\
& -0.4 \\
& (0.089 \\
& \text { yes } \\
& \text { yes } \\
& \text { yes } \\
& \text { no }
\end{aligned}
$$

$\begin{array}{llllllllllll}0.246 & 0.643 & 0.246 & 0.643 & 0.246 & 0.643 & 0.225 & 0.626 & 0.225 & 0.626 & 0.225 & 0.626 \\ 0.041 & 0.213 & 0.041 & 0.213 & 0.041 & 0.213 & 0.042 & 0.203 & 0.042 & 0.203 & 0.042 & 0.203 \\ 0.033 & & 0.033 & & 0.033 & & 0.032 & & 0.033 & & 0.032 & \\ & 0.213 & & 0.000 & & 0.000 & & 0.000 & & 0.000 & & 0.000 \\ 13,664 & 12,132 & 13,664 & 12,132 & 13,664 & 12,132 & 13,664 & 12,132 & 13,664 & 12,132 & 13,664 & 12,132 \\ 0.083 & 0.102 & 0.083 & 0.102 & 0.083 & 0.102 & 0.083 & 0.103 & 0.083 & 0.103 & 0.083 & 0.103\end{array}$

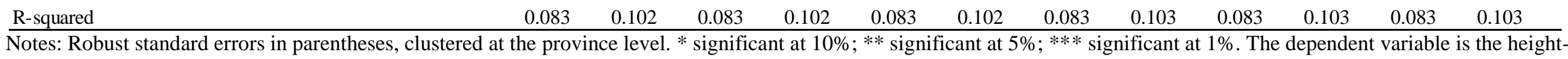
for-age z-score. All regressions include province fixed effects, and month-of-birth fixed effects. Child controls include ethnicity (Akan (reference category), Northern Mande, Southern Mande, Krou, Voltaique/Gur, naturalized Ivorian or non-Ivorian) and religion (Muslim, Christian, and other (reference category)). Household head controls include age, gender, and education. Mother controls include age, education, and marital status. In specifications that allow for a differential gender impact (columns 7-12), the coefficient estimates on interactions between 'Conflict region' or 'Exposure' variables and the female dummy are jointly statistically insignificant and not shown. Estimates are weighted by inverse sampling probability. Data sources: 2002 and 2008 Côte d'Ivoire HLSS, 2006 Côte d'Ivoire MICS3, and Raleigh et al. (2010). 
Table 4. Impact of Conflict on Child Health. Alternative Baseline Cohort.

\section{Conflict region*War Cohort}

Conflict region*War Cohort*Female

Conflict region*Exposure 0-24 months

Conflict region*Exposure at least 25 months

Conflict region*Exposure 0-24 months*Female

Conflict region*Exposure at least 25 months*Female

Conflict region*Exposure (no. of months)

Conflict region*Exposure (no. of months)*Female

Female

Rural household

Province-specific trends

Child controls

Household head controls

Mother controls

p-value F-test of zero effect of:

Child ethnicity

Child religion

Household head's characteristics

Mother's characteristics

Observations

R-squared

0.113

$(0.069) \quad(0.087)$

$-0.364 * * \quad-0.380 * *$

(0.140)

(0.150)

$\begin{array}{ll}-1.000 * * * & -1.191 * * * \\ (0.305) & (0.350) \\ -0.852 * * & -0.990 * * \\ (0.338) & (0.373)\end{array}$

yes yes yes

yes yes

yes no

0.49

0.903

0.009

120

0.094

0.120

10,128
[6]

[7]

[8]

[9]

$\begin{array}{ll}-0.976^{* * * *} & -1.126 * * * \\ (0.301) & (0.337) \\ 0.240^{*} & 0.156 \\ (0.121) & (0.136)\end{array}$

(0.121) (0.136)

$\begin{array}{ll}-1.249 * * * & -1.471 * * * \\ (0.303) & (0.358) \\ -0.843^{* *} & -1.013^{* *} \\ (0.342) & (0.383) \\ 0.557^{* * *} & 0.555 * * * \\ (0.119) & (0.125) \\ 0.047 & 0.039 \\ (0.088) & (0.111)\end{array}$

$-0.021 * * \quad-0.024 * *$

(0.008) (0.009)

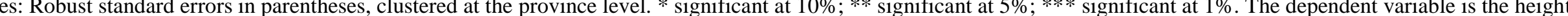

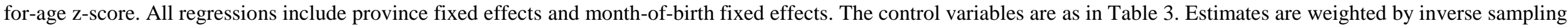
probability. Data sources: 2002 and 2008 Côte d'Ivoire HLSS, 2006 Côte d'Ivoire MICS3, and Raleigh et al. (2010). 
Table 5. Impact of Conflict on Child Health. Baseline Regressions on Different Sub-samples.

\begin{tabular}{|c|c|c|c|c|c|c|c|c|}
\hline & $\begin{array}{c}{[1]} \\
\text { Poor }\end{array}$ & $\begin{array}{c}{[2]} \\
\text { Non-poor }\end{array}$ & $\begin{array}{l}\text { [3] } \\
\text { Girls }\end{array}$ & $\begin{array}{c}{[4]} \\
\text { Boys }\end{array}$ & $\begin{array}{c}{[5]} \\
\text { Rural }\end{array}$ & $\begin{array}{c}{[6]} \\
\text { Urban }\end{array}$ & $\begin{array}{c}{[7]} \\
\text { Head is } \\
\text { educated }\end{array}$ & $\begin{array}{c}\quad[8] \\
\text { Head is not } \\
\text { educated }\end{array}$ \\
\hline Conflict region*War Cohort & $\begin{array}{c}-0.516^{*} \\
(0.268)\end{array}$ & $\begin{array}{c}-0.382 * \\
(0.217)\end{array}$ & $\begin{array}{c}-0.602 * * \\
(0.269)\end{array}$ & $\begin{array}{c}-0.297 * * \\
(0.141)\end{array}$ & $\begin{array}{c}-0.655^{* *} \\
(0.238)\end{array}$ & $\begin{array}{l}-0.017 \\
(0.213)\end{array}$ & $\begin{array}{l}-0.285 \\
(0.274)\end{array}$ & $\begin{array}{c}-0.507 * * \\
(0.216)\end{array}$ \\
\hline Conflict region*War Cohort*Female & $\begin{array}{c}0.251 \\
(0.215)\end{array}$ & $\begin{array}{l}-0.269 \\
(0.178)\end{array}$ & & & $\begin{array}{l}-0.047 \\
(0.139)\end{array}$ & $\begin{array}{l}0.348 * \\
(0.179)\end{array}$ & $\begin{array}{l}-0.035 \\
(0.158)\end{array}$ & $\begin{array}{l}-0.020 \\
(0.224)\end{array}$ \\
\hline Female & $\begin{array}{c}0.317 * * \\
(0.129)\end{array}$ & $\begin{array}{c}0.036 \\
(0.119)\end{array}$ & & & $\begin{array}{c}0.217 \\
(0.129)\end{array}$ & $\begin{array}{c}0.152 \\
(0.166)\end{array}$ & $\begin{array}{c}0.111 \\
(0.069)\end{array}$ & $\begin{array}{c}0.179 \\
(0.171)\end{array}$ \\
\hline Rural household & $\begin{array}{l}-0.087 \\
(0.093)\end{array}$ & $\begin{array}{c}-0.464 * * * \\
(0.096)\end{array}$ & $\begin{array}{c}-0.465 * * * \\
(0.082)\end{array}$ & $\begin{array}{c}-0.511 * * * \\
(0.119)\end{array}$ & & & $\begin{array}{c}-0.589 * * * \\
(0.083)\end{array}$ & $\begin{array}{c}-0.378 * * * \\
(0.106)\end{array}$ \\
\hline \multicolumn{9}{|c|}{ p-value t-test of equality of coefficients on Conflict Region*War Cohort across sub-samples } \\
\hline $\begin{array}{l}\text { Observations } \\
\text { R-squared }\end{array}$ & $\begin{array}{l}6,700 \\
0.088\end{array}$ & $\begin{array}{l}8,030 \\
0.091\end{array}$ & $\begin{array}{l}7,340 \\
0.088\end{array}$ & $\begin{array}{l}7,811 \\
0.095\end{array}$ & $\begin{array}{l}8,753 \\
0.098\end{array}$ & $\begin{array}{l}6,398 \\
0.069\end{array}$ & $\begin{array}{l}6,696 \\
0.117\end{array}$ & $\begin{array}{l}8,429 \\
0.077\end{array}$ \\
\hline $\begin{array}{l}\text { Notes: Robust standard errors in parenthese } \\
\text { for-age z-score. All regressions include pro } \\
\text { wealth is below average. The asset index is } \\
\text { toilet, and access to natural gas, coal or elec } \\
\text { percent of their joint variance, and has been } \\
\text { 'Conflict region' or 'War Cohort' and the fen } \\
2002 \text { and } 2008 \text { Côte d'Ivoire HLSS, } 2006 \text { C }\end{array}$ & $\begin{array}{l}\text { ed at the } \\
\text { ed effects, } \\
\text { ed based o } \\
\text { r cooking. } \\
\text { dized to ha } \\
\text { imy are jo } \\
\text { ire MICS? }\end{array}$ & $\begin{array}{l}\text { ce level. * } \\
\text { h-of-birth } \\
n \text { types of } \\
\text { ndex is the } \\
\text { o mean an } \\
\text { tatistically }\end{array}$ & $\begin{array}{l}\text { ficant at } 10 \% \\
\text { effects, and } \\
\text { s: living in d } \\
\text { factor extra } \\
\text { t variance. Ir } \\
\text { nificant and }\end{array}$ & $\begin{array}{l}\text { significan } \\
\text { ince-specif } \\
\text { ing with ce } \\
\text { using princ } \\
\text { columns ot } \\
\text { hewn }\end{array}$ & $\begin{array}{l}6 ; * * * \text { si } \\
\text { e trends. } \\
\text { walls, ce } \\
\text { omponen } \\
\text { lan } 3 \text { and } \\
\text { sare weis }\end{array}$ & $\begin{array}{l}\text { at } 1 \% . \mathrm{T} \\
\text { olds are c } \\
\text { or, metal } \\
\text { sis on the } \\
\text { pefficient } \\
\text { inverse s }\end{array}$ & $\begin{array}{l}\text { pendent } v \\
\text { ied as poo } \\
\text { ment roof, } \\
\text { n compone } \\
\text { lates on in } \\
\text { ing probab }\end{array}$ & $\begin{array}{l}\text { e is the height } \\
\mathrm{n} \text { index of asse } \\
\text { ricity, phone, } \\
\text { explains } 47 \\
\text { ions between } \\
\text { Data sources: }\end{array}$ \\
\hline
\end{tabular}


Table 6. Placebo Test

\begin{tabular}{|c|c|c|c|c|c|c|c|c|c|c|c|c|}
\hline & [1] & [2] & [3] & [4] & [5] & [6] & [7] & [8] & [9] & [10] & [11] & [12] \\
\hline Conflict Region*War Cohort & $\begin{array}{l}0.127 \\
(0.131)\end{array}$ & $\begin{array}{l}0.134 \\
(0.159)\end{array}$ & $\begin{array}{l}0.097 \\
(0.127)\end{array}$ & $\begin{array}{l}0.095 \\
(0.158)\end{array}$ & $\begin{array}{l}0.126 \\
(0.133)\end{array}$ & $\begin{array}{l}0.132 \\
(0.158)\end{array}$ & $\begin{array}{l}0.443 \\
(0.258)\end{array}$ & $\begin{array}{l}0.427 \\
(0.263)\end{array}$ & $\begin{array}{l}0.415^{*} \\
(0.239)\end{array}$ & $\begin{array}{l}0.397 \\
(0.245)\end{array}$ & $\begin{array}{l}0.435 \\
(0.255)\end{array}$ & $\begin{array}{l}0.419 \\
(0.260)\end{array}$ \\
\hline Conflict Region*War Cohort*Female & & & & & & & $\begin{array}{l}-0.748^{*} \\
(0.416)\end{array}$ & $\begin{array}{l}-0.725^{*} \\
(0.418)\end{array}$ & $\begin{array}{l}-0.721 * \\
(0.406)\end{array}$ & $\begin{array}{l}-0.710 \\
(0.413)\end{array}$ & $\begin{array}{l}-0.737 * \\
(0.416)\end{array}$ & $\begin{array}{l}-0.721 \\
(0.418)\end{array}$ \\
\hline Conflict Region*Female & & & & & & & $\begin{array}{l}0.192 * * \\
(0.082)\end{array}$ & $\begin{array}{l}0.168 * * \\
(0.073)\end{array}$ & $\begin{array}{l}0.147^{*} \\
(0.076)\end{array}$ & $\begin{array}{l}0.126^{*} \\
(0.071)\end{array}$ & $\begin{array}{l}0.198 * * \\
(0.076)\end{array}$ & $\begin{array}{l}0.175 * * \\
(0.068)\end{array}$ \\
\hline War Cohort*Female & & & & & & & $\begin{array}{l}0.426 \\
(0.275)\end{array}$ & $\begin{array}{l}0.475 \\
(0.285)\end{array}$ & $\begin{array}{l}0.430 \\
(0.273)\end{array}$ & $\begin{array}{l}0.479 \\
(0.284)\end{array}$ & $\begin{array}{l}0.419 \\
(0.268)\end{array}$ & $\begin{array}{l}0.468 \\
(0.278)\end{array}$ \\
\hline Female & $\begin{array}{l}0.106^{*} \\
(0.059)\end{array}$ & $\begin{array}{l}0.116^{*} \\
(0.058)\end{array}$ & $\begin{array}{l}0.119 * \\
(0.058)\end{array}$ & $\begin{array}{l}0.128 * * \\
(0.057)\end{array}$ & $\begin{array}{l}0.110^{*} \\
(0.060)\end{array}$ & $\begin{array}{l}0.121 * \\
(0.059)\end{array}$ & $\begin{array}{l}-0.017 \\
(0.065)\end{array}$ & $\begin{array}{l}0.001 \\
(0.061)\end{array}$ & $\begin{array}{l}0.025 \\
(0.063)\end{array}$ & $\begin{array}{l}0.041 \\
(0.059)\end{array}$ & $\begin{array}{l}-0.017 \\
(0.064)\end{array}$ & $\begin{array}{l}0.001 \\
(0.061)\end{array}$ \\
\hline Rural & $\begin{array}{l}-0.352 * * * \\
(0.065)\end{array}$ & $\begin{array}{l}-0.365^{* * *} \\
(0.067)\end{array}$ & $\begin{array}{l}-0.296 * * * \\
(0.056)\end{array}$ & $\begin{array}{l}-0.313 * * * \\
(0.060)\end{array}$ & $\begin{array}{l}-0.333 * * * \\
(0.065)\end{array}$ & $\begin{array}{l}-0.344 * * * \\
(0.064)\end{array}$ & $\begin{array}{l}-0.341 * * * \\
(0.066)\end{array}$ & $\begin{array}{l}-0.357 * * * \\
(0.067)\end{array}$ & $\begin{array}{l}-0.289 * * * \\
(0.053)\end{array}$ & $\begin{array}{l}-0.309 * * * \\
(0.057)\end{array}$ & $\begin{array}{l}-0.322 * * * \\
(0.066)\end{array}$ & $\begin{array}{l}-0.336 * * * \\
(0.065)\end{array}$ \\
\hline Province specific trends & no & yes & no & yes & no & yes & no & yes & no & yes & no & yes \\
\hline Mother controls & no & no & yes & yes & no & no & no & no & yes & yes & no & no \\
\hline Household head controls & no & no & no & no & yes & yes & no & no & no & no & yes & yes \\
\hline \multicolumn{13}{|l|}{$p$-value F-test of zero effect of: } \\
\hline Mother's characteristics & & & 0.000 & 0.000 & & & & & 0.000 & 0.000 & & \\
\hline Household head's characteristics & & & & & 0.107 & 0.140 & & & & & 0.064 & 0.096 \\
\hline Observations & 4,076 & 4,076 & 4,066 & 4,066 & 4,042 & 4,042 & 4,076 & 4,076 & 4,066 & 4,066 & 4,042 & 4,042 \\
\hline R-squared & 0.187 & 0.196 & 0.197 & 0.205 & 0.188 & 0.197 & 0.189 & 0.198 & 0.199 & 0.207 & 0.190 & 0.199 \\
\hline
\end{tabular}

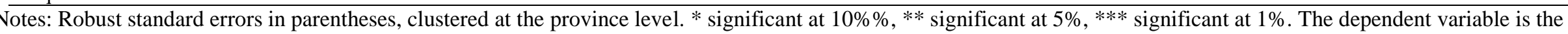

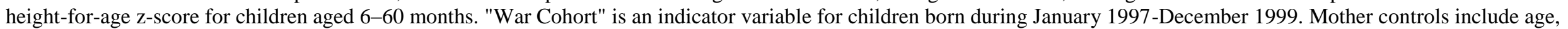

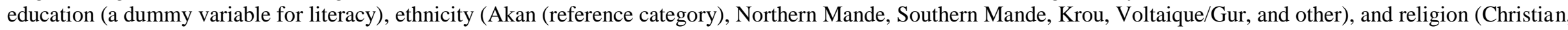

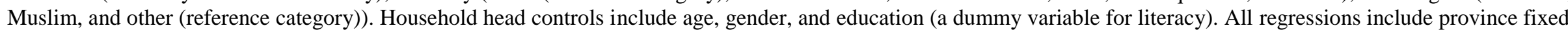

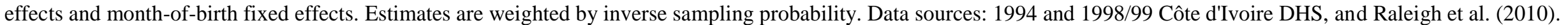


Table 7. Correlation Matrix for Number of Conflict Events and Share of Households Reporting At Least One Type of Victimization

\begin{tabular}{|c|c|c|c|c|c|}
\hline & Conflict Region & Victimized & $\begin{array}{c}\text { Victimized: } \\
\text { Economic losses }\end{array}$ & $\begin{array}{l}\text { Victimized: } \\
\text { Health }\end{array}$ & $\begin{array}{c}\text { Victimized: } \\
\text { Displacement }\end{array}$ \\
\hline Victimized & $0.249 *$ & & & & \\
\hline Victimized: Economic losses & $0.249 *$ & $0.992 *$ & & & \\
\hline Victimized: Health impairment & $0.233 *$ & $0.661 *$ & $0.653 *$ & & \\
\hline Victimized: Displacement & 0.228 & $0.498 *$ & $0.526^{*}$ & $0.772 *$ & \\
\hline Victimized: Victim of violence & $0.331 *$ & $0.554 *$ & $0.581 *$ & $0.832 *$ & $0.943 *$ \\
\hline
\end{tabular}

Notes: * significant at 10\%. Data sources: 2008 Côte d'Ivoire HLSS and Raleigh et al. (2010).

Table 8. Selection into Victimization (Post-Conflict Survey)

\begin{tabular}{|c|c|c|c|c|c|c|c|c|c|c|}
\hline & [1] & {$[2]$} & [3] & [4] & {$[5]$} & [6] & [7] & [8] & [9] & [10] \\
\hline & \multicolumn{2}{|c|}{ Victimized } & \multicolumn{2}{|c|}{$\begin{array}{l}\text { Victimized: Economic } \\
\text { losses } \\
\end{array}$} & \multicolumn{2}{|c|}{$\begin{array}{l}\text { Victimized: Health } \\
\text { impairment }\end{array}$} & \multicolumn{2}{|c|}{$\begin{array}{c}\text { Victimized: } \\
\text { Displacement }\end{array}$} & \multicolumn{2}{|c|}{$\begin{array}{l}\text { Victimized: Victim of } \\
\text { violence }\end{array}$} \\
\hline & Full & $\begin{array}{c}\text { Non- } \\
\text { migrants }\end{array}$ & Full & $\begin{array}{c}\text { Non- } \\
\text { migrants }\end{array}$ & Full & $\begin{array}{c}\text { Non- } \\
\text { migrants }\end{array}$ & Full & $\begin{array}{c}\text { Non- } \\
\text { migrants }\end{array}$ & Full & $\begin{array}{c}\text { Non- } \\
\text { migrants }\end{array}$ \\
\hline Rural household & $\begin{array}{l}-0.165 \\
(0.133)\end{array}$ & $\begin{array}{l}-0.070 \\
(0.144)\end{array}$ & $\begin{array}{l}-0.085 \\
(0.058)\end{array}$ & $\begin{array}{l}-0.053 \\
(0.068)\end{array}$ & $\begin{array}{l}-0.011 \\
(0.029)\end{array}$ & $\begin{array}{l}-0.010 \\
(0.032)\end{array}$ & $\begin{array}{l}-0.042 \\
(0.039)\end{array}$ & $\begin{array}{c}0.012 \\
(0.034)\end{array}$ & $\begin{array}{l}-0.019 \\
(0.034)\end{array}$ & $\begin{array}{c}0.000 \\
(0.035)\end{array}$ \\
\hline Ethnicity: Northern Mande & $\begin{array}{l}-0.393 \\
(0.265)\end{array}$ & $\begin{array}{l}-0.503 \\
(0.301)\end{array}$ & $\begin{array}{l}-0.127 \\
(0.085)\end{array}$ & $\begin{array}{l}-0.116 \\
(0.093)\end{array}$ & $\begin{array}{l}-0.128 \\
(0.093)\end{array}$ & $\begin{array}{l}-0.179 \\
(0.106)\end{array}$ & $\begin{array}{l}-0.074 \\
(0.065)\end{array}$ & $\begin{array}{l}-0.111 \\
(0.065)\end{array}$ & $\begin{array}{l}-0.079 \\
(0.061)\end{array}$ & $\begin{array}{l}-0.103 \\
(0.069)\end{array}$ \\
\hline Ethnicity: Southern Mande & $\begin{array}{c}1.287 * * * \\
(0.394)\end{array}$ & $\begin{array}{l}1.228 * * \\
(0.453)\end{array}$ & $\begin{array}{l}0.327 * \\
(0.180)\end{array}$ & $\begin{array}{c}0.330 \\
(0.214)\end{array}$ & $\begin{array}{c}0.332 * * \\
(0.121)\end{array}$ & $\begin{array}{c}0.322 * * \\
(0.125)\end{array}$ & $\begin{array}{l}0.232 * * \\
(0.093)\end{array}$ & $\begin{array}{c}0.207 \\
(0.122)\end{array}$ & $\begin{array}{c}0.288 * * * \\
(0.070)\end{array}$ & $\begin{array}{c}0.260 * * * \\
(0.075)\end{array}$ \\
\hline Ethnicity: Krou & $\begin{array}{c}0.672 \\
(0.391)\end{array}$ & $\begin{array}{c}0.569 \\
(0.408)\end{array}$ & $\begin{array}{c}0.040 \\
(0.114)\end{array}$ & $\begin{array}{c}0.024 \\
(0.110)\end{array}$ & $\begin{array}{c}0.283 * * \\
(0.132)\end{array}$ & $\begin{array}{l}0.285^{*} \\
(0.141)\end{array}$ & $\begin{array}{c}0.095 \\
(0.092)\end{array}$ & $\begin{array}{c}0.051 \\
(0.079)\end{array}$ & $\begin{array}{c}0.219 * * \\
(0.099)\end{array}$ & $\begin{array}{c}0.200 \\
(0.116)\end{array}$ \\
\hline Ethnicity: Voltaique/Gur & $\begin{array}{l}-0.396 \\
(0.451)\end{array}$ & $\begin{array}{l}-0.365 \\
(0.510)\end{array}$ & $\begin{array}{l}-0.155 \\
(0.113)\end{array}$ & $\begin{array}{l}-0.105 \\
(0.127)\end{array}$ & $\begin{array}{l}-0.027 \\
(0.147)\end{array}$ & $\begin{array}{l}-0.050 \\
(0.164)\end{array}$ & $\begin{array}{l}-0.076 \\
(0.096)\end{array}$ & $\begin{array}{l}-0.063 \\
(0.110)\end{array}$ & $\begin{array}{l}-0.109 \\
(0.094)\end{array}$ & $\begin{array}{l}-0.117 \\
(0.101)\end{array}$ \\
\hline Ethnicity: Naturalized Ivorian & $\begin{array}{c}0.298 \\
(0.784)\end{array}$ & $\begin{array}{c}0.315 \\
(0.779)\end{array}$ & $\begin{array}{c}0.045 \\
(0.179)\end{array}$ & $\begin{array}{c}0.093 \\
(0.195)\end{array}$ & $\begin{array}{c}0.120 \\
(0.286)\end{array}$ & $\begin{array}{c}0.147 \\
(0.302)\end{array}$ & $\begin{array}{l}-0.056 \\
(0.223)\end{array}$ & $\begin{array}{l}-0.019 \\
(0.214)\end{array}$ & $\begin{array}{l}-0.113 \\
(0.080)\end{array}$ & $\begin{array}{c}-0.193 * * * \\
(0.057)\end{array}$ \\
\hline Ethnicity: Non-Ivorian & $\begin{array}{l}-0.094 \\
(0.196)\end{array}$ & $\begin{array}{l}-0.102 \\
(0.219)\end{array}$ & $\begin{array}{l}-0.062 \\
(0.074)\end{array}$ & $\begin{array}{l}-0.050 \\
(0.078)\end{array}$ & $\begin{array}{l}-0.026 \\
(0.072)\end{array}$ & $\begin{array}{l}-0.041 \\
(0.078)\end{array}$ & $\begin{array}{c}0.047 \\
(0.058)\end{array}$ & $\begin{array}{c}0.043 \\
(0.058)\end{array}$ & $\begin{array}{l}-0.044 \\
(0.036)\end{array}$ & $\begin{array}{l}-0.060 \\
(0.036)\end{array}$ \\
\hline Muslim & $\begin{array}{l}-0.171 \\
(0.157)\end{array}$ & $\begin{array}{l}-0.066 \\
(0.195)\end{array}$ & $\begin{array}{l}-0.035 \\
(0.082)\end{array}$ & $\begin{array}{l}-0.002 \\
(0.085)\end{array}$ & $\begin{array}{l}-0.029 \\
(0.085)\end{array}$ & $\begin{array}{l}-0.022 \\
(0.095)\end{array}$ & $\begin{array}{c}-0.086^{*} \\
(0.042)\end{array}$ & $\begin{array}{l}-0.048 \\
(0.046)\end{array}$ & $\begin{array}{l}-0.001 \\
(0.018)\end{array}$ & $\begin{array}{c}0.020 \\
(0.024)\end{array}$ \\
\hline Christian & $\begin{array}{c}-0.219 * * \\
(0.092)\end{array}$ & $\begin{array}{l}-0.155 \\
(0.122)\end{array}$ & $\begin{array}{c}-0.102 * \\
(0.051)\end{array}$ & $\begin{array}{l}-0.064 \\
(0.063)\end{array}$ & $\begin{array}{l}-0.063 \\
(0.037)\end{array}$ & $\begin{array}{l}-0.061 \\
(0.043)\end{array}$ & $\begin{array}{l}-0.011 \\
(0.030)\end{array}$ & $\begin{array}{c}0.002 \\
(0.029)\end{array}$ & $\begin{array}{c}-0.056^{* * *} \\
(0.019)\end{array}$ & $\begin{array}{l}-0.039 * \\
(0.021)\end{array}$ \\
\hline Head's age & $\begin{array}{c}0.004 \\
(0.003)\end{array}$ & $\begin{array}{c}0.005 \\
(0.003)\end{array}$ & $\begin{array}{c}0.003 \\
(0.002)\end{array}$ & $\begin{array}{c}0.003 \\
(0.002)\end{array}$ & $\begin{array}{c}0.002 * * \\
(0.001)\end{array}$ & $\begin{array}{l}0.002 * \\
(0.001)\end{array}$ & $\begin{array}{c}-0.001 * \\
(0.001)\end{array}$ & $\begin{array}{l}-0.001 \\
(0.001)\end{array}$ & $\begin{array}{l}-0.000 \\
(0.001)\end{array}$ & $\begin{array}{l}-0.000 \\
(0.001)\end{array}$ \\
\hline Head's education & $\begin{array}{c}0.078 \\
(0.095)\end{array}$ & $\begin{array}{c}0.087 \\
(0.090)\end{array}$ & $\begin{array}{l}-0.028 \\
(0.043)\end{array}$ & $\begin{array}{l}-0.003 \\
(0.045)\end{array}$ & $\begin{array}{l}-0.002 \\
(0.041)\end{array}$ & $\begin{array}{c}0.004 \\
(0.040)\end{array}$ & $\begin{array}{c}0.040 \\
(0.034)\end{array}$ & $\begin{array}{c}0.024 \\
(0.030)\end{array}$ & $\begin{array}{c}0.069 * * * \\
(0.018)\end{array}$ & $\begin{array}{c}0.062 * * * \\
(0.021)\end{array}$ \\
\hline Head is male & $\begin{array}{l}-0.091 \\
(0.130)\end{array}$ & $\begin{array}{l}-0.133 \\
(0.143)\end{array}$ & $\begin{array}{c}0.028 \\
(0.048)\end{array}$ & $\begin{array}{c}0.024 \\
(0.056)\end{array}$ & $\begin{array}{l}-0.089 \\
(0.063)\end{array}$ & $\begin{array}{l}-0.098 \\
(0.073)\end{array}$ & $\begin{array}{l}-0.040 \\
(0.030)\end{array}$ & $\begin{array}{l}-0.049 \\
(0.031)\end{array}$ & $\begin{array}{l}-0.024 \\
(0.025)\end{array}$ & $\begin{array}{l}-0.037 \\
(0.026)\end{array}$ \\
\hline Head is married & $\begin{array}{c}0.379 * * * \\
(0.096)\end{array}$ & $\begin{array}{c}0.336^{* * * *} \\
(0.089)\end{array}$ & $\begin{array}{c}0.225 * * * \\
(0.046)\end{array}$ & $\begin{array}{c}0.219 * * * \\
(0.049)\end{array}$ & $\begin{array}{c}0.049 \\
(0.055)\end{array}$ & $\begin{array}{c}0.051 \\
(0.056)\end{array}$ & $\begin{array}{c}0.078 * * \\
(0.032)\end{array}$ & $\begin{array}{l}0.053^{*} \\
(0.030)\end{array}$ & $\begin{array}{l}0.032 * \\
(0.016)\end{array}$ & $\begin{array}{c}0.026 \\
(0.016)\end{array}$ \\
\hline$p$-value F-test of zero joint & $o f:$ & & & & & & & & & \\
\hline Head's ethnicity & 0.024 & 0.085 & 0.232 & 0.334 & 0.002 & 0.008 & 0.049 & 0.005 & 0.001 & 0.000 \\
\hline Head's religion & 0.068 & 0.257 & 0.118 & 0.481 & 0.136 & 0.172 & 0.129 & 0.518 & 0.014 & 0.016 \\
\hline Head's other characteristics & 0.012 & 0.017 & 0.000 & 0.000 & 0.052 & 0.138 & 0.051 & 0.167 & 0.005 & 0.022 \\
\hline Observations & 5,256 & 4,739 & 5,610 & 5,057 & 5,713 & 5,143 & 5,707 & 5,137 & 5,796 & 5,221 \\
\hline R-squared & 0.332 & 0.358 & 0.226 & 0.239 & 0.164 & 0.178 & 0.260 & 0.286 & 0.253 & 0.262 \\
\hline
\end{tabular}

Notes: Robust standard errors in parentheses, clustered at the province level. * significant at 10\%; ** significant at 5\%; *** significant at $1 \%$. The dependent variables are the victimization indices. Regressions are at the household level and include province fixed effects. Estimates are weighted by inverse sampling probability. Data source: 2008 Côte d'Ivoire HLSS. 
Table 9. Impact of Household Victimization on Child Health (Post-Conflict Survey)

\begin{tabular}{|c|c|c|c|c|c|c|c|c|c|c|c|c|}
\hline & {$[1]$} & {$[2]$} & [3] & {$[4]$} & {$[5]$} & {$[6]$} & [7] & {$[8]$} & [9] & {$[10]$} & {$[11]$} & {$[12]$} \\
\hline \multicolumn{13}{|l|}{ Panel A. Full sample: } \\
\hline Victimized & $\begin{array}{c}-0.709 * \\
(0.345)\end{array}$ & $\begin{array}{c}-0.699 * \\
(0.343)\end{array}$ & $\begin{array}{c}-0.761 * * \\
(0.357)\end{array}$ & $\begin{array}{c}-0.743^{*} \\
(0.361)\end{array}$ & $\begin{array}{c}-0.721 * \\
(0.393)\end{array}$ & $\begin{array}{l}-0.666 \\
(0.394)\end{array}$ & $\begin{array}{c}-0.927^{*} \\
(0.443)\end{array}$ & $\begin{array}{c}-0.925^{*} \\
(0.450)\end{array}$ & $\begin{array}{c}-1.029 * * \\
(0.482)\end{array}$ & $\begin{array}{c}-0.990 * \\
(0.495)\end{array}$ & $\begin{array}{c}-0.945 * * \\
(0.443)\end{array}$ & $\begin{array}{c}-0.887 * \\
(0.453)\end{array}$ \\
\hline Victimized*Female & & & & & & & $\begin{array}{c}0.516 \\
(0.761)\end{array}$ & $\begin{array}{c}0.535 \\
(0.785)\end{array}$ & $\begin{array}{c}0.632 \\
(0.934)\end{array}$ & $\begin{array}{c}0.580 \\
(0.945)\end{array}$ & $\begin{array}{c}0.530 \\
(0.866)\end{array}$ & $\begin{array}{c}0.521 \\
(0.885)\end{array}$ \\
\hline Observations & 2,026 & 2,026 & 1,975 & 1,975 & 1,821 & 1,821 & 2,026 & 2,026 & 1,975 & 1,975 & 1,821 & 1,821 \\
\hline R-squared & 0.057 & 0.078 & 0.070 & 0.090 & 0.084 & 0.103 & 0.057 & 0.078 & 0.070 & 0.091 & 0.085 & 0.104 \\
\hline \multicolumn{13}{|l|}{ Panel B. Non-migrants: } \\
\hline Victimized & $\begin{array}{c}-0.778 * * \\
(0.317)\end{array}$ & $\begin{array}{c}-0.809 * * \\
(0.315)\end{array}$ & $\begin{array}{c}-0.836^{* *} \\
(0.304)\end{array}$ & $\begin{array}{c}-0.861 * * \\
(0.314)\end{array}$ & $\begin{array}{c}-0.817 * * \\
(0.343)\end{array}$ & $\begin{array}{c}-0.802 * * \\
(0.358)\end{array}$ & $\begin{array}{c}-1.090 * \\
(0.573)\end{array}$ & $\begin{array}{c}-1.102 * \\
(0.598)\end{array}$ & $\begin{array}{c}-1.219 * \\
(0.640)\end{array}$ & $\begin{array}{c}-1.203^{*} \\
(0.664)\end{array}$ & $\begin{array}{c}-1.065^{*} \\
(0.611)\end{array}$ & $\begin{array}{l}-1.038 \\
(0.645)\end{array}$ \\
\hline Victimized*Female & & & & & & & $\begin{array}{c}0.766 \\
(0.966)\end{array}$ & $\begin{array}{c}0.720 \\
(0.987)\end{array}$ & $\begin{array}{c}0.930 \\
(1.132)\end{array}$ & $\begin{array}{c}0.833 \\
(1.148)\end{array}$ & $\begin{array}{c}0.616 \\
(1.019)\end{array}$ & $\begin{array}{c}0.586 \\
(1.045)\end{array}$ \\
\hline Observations & 1,686 & 1,686 & 1,642 & 1,642 & 1,509 & 1,509 & 1,686 & 1,686 & 1,642 & 1,642 & 1,509 & 1,509 \\
\hline R-squared & 0.063 & 0.083 & 0.079 & 0.097 & 0.095 & 0.112 & 0.064 & 0.084 & 0.080 & 0.098 & 0.095 & 0.113 \\
\hline \multicolumn{13}{|c|}{ p-value t-test that "Victimized" coefficients for migrant and non-migrant households are equal } \\
\hline & 0.454 & 0.383 & 0.472 & 0.410 & 0.556 & 0.468 & 0.484 & 0.416 & 0.511 & 0.446 & 0.598 & 0.510 \\
\hline Province specific trends & no & yes & no & yes & no & yes & no & yes & no & yes & no & yes \\
\hline Child controls & no & no & yes & yes & yes & yes & no & no & yes & yes & yes & yes \\
\hline Household head controls & no & no & yes & yes & no & no & no & no & yes & yes & no & no \\
\hline Mother controls & no & no & no & no & yes & yes & no & no & no & no & yes & yes \\
\hline
\end{tabular}


Table 10. Impact of Different Types of Household Victimization on Child Health (Post-Conflict Survey)
[1]
[2]
[3]
[4]
[5]
[6]

Panel A. Full sample:

Victimized: Economic losses

$\begin{array}{cccccc}-1.050^{* * *} & -1.050 * * * & -1.188 * * * & -1.187 * * * & -0.847 * & -0.822 * \\ (0.345) & (0.356) & (0.355) & (0.376) & (0.408) & (0.417) \\ -0.144 & -0.156 & -0.185 & -0.188 & -0.287 & -0.274 \\ (0.305) & (0.312) & (0.308) & (0.320) & (0.290) & (0.295) \\ 0.418 & 0.440 & 0.565 * & 0.587 * & 0.465 & 0.489 \\ (0.360) & (0.359) & (0.309) & (0.306) & (0.382) & (0.381) \\ 0.015 & 0.020 & -0.012 & -0.009 & -0.103 & -0.108 \\ (0.371) & (0.377) & (0.387) & (0.399) & (0.390) & (0.402)\end{array}$

Victimized: Health impairment

\begin{tabular}{llllll}
2,026 & 2,026 & 1,975 & 1,975 & 1,821 & 1,821 \\
0.060 & 0.081 & 0.074 & 0.095 & 0.087 & 0.106 \\
\hline
\end{tabular}

Panel B. Non-migrants:

Victimized: Economic losses

$\begin{array}{cccccc}-1.054 * * * & -1.066^{* * *} & -1.155^{* * *} & -1.164 * * * & -0.741 * & -0.713 * \\ (0.353) & (0.369) & (0.352) & (0.374) & (0.405) & (0.408) \\ 0.006 & 0.035 & -0.003 & 0.022 & -0.132 & -0.098 \\ (0.439) & (0.444) & (0.435) & (0.443) & (0.423) & (0.422) \\ 0.370 & 0.338 & 0.470 & 0.443 & 0.251 & 0.245 \\ (0.425) & (0.445) & (0.386) & (0.409) & (0.463) & (0.488) \\ -0.105 & -0.118 & -0.123 & -0.135 & -0.168 & -0.209 \\ (0.407) & (0.419) & (0.415) & (0.432) & (0.418) & (0.433)\end{array}$

Observations

\begin{tabular}{llllll}
1,686 & 1,686 & 1,642 & 1,642 & 1,509 & 1,509 \\
0.066 & 0.086 & 0.083 & 0.101 & 0.096 & 0.113 \\
\hline
\end{tabular}

p-value t-test that "Victimized" coefficients for migrant and non-migrant households are equal

$\begin{array}{lllllll}\text { Victimized: } \text { Economic losses } & 0.625 & 0.661 & 0.609 & 0.618 & 0.883 & 0.902 \\ \text { Victimized: Health impairment } & 0.767 & 0.764 & 0.637 & 0.606 & 0.890 & 0.914 \\ \text { Victimized: Displacement } & 0.934 & 0.874 & 0.973 & 0.938 & 0.765 & 0.750 \\ \text { Victimized: Victim of violence } & 0.964 & 0.973 & 0.896 & 0.976 & 0.771 & 0.984\end{array}$

Province specific trends

Child controls

Household head controls

$\begin{array}{llllll}\text { no } & \text { yes } & \text { no } & \text { yes } & \text { no } & \text { yes } \\ \text { no } & \text { no } & \text { yes } & \text { yes } & \text { yes } & \text { yes } \\ \text { no } & \text { no } & \text { yes } & \text { yes } & \text { no } & \text { no } \\ \text { no } & \text { no } & \text { no } & \text { no } & \text { yes } & \text { yes }\end{array}$

Mother controls

no

no no

Notes: Robust standard errors in parentheses, clustered at the province level. * significant at 10\%; ** significant at 5\%; *** significant at $1 \%$. All regressions include indicator variables for rural residence and female child (coefficients not shown), province fixed effects, and month-of-birth fixed effects. Non-migrants households have lived in their current location since before the start of the war. Estimates are weighted by inverse sampling probability. Data source: 2008 Côte d'Ivoire HLSS. 
Table 11. Joint impact of Conflict and Household Victimization on Child Health (Pre- and Post-Conflict Surveys)

\begin{tabular}{|c|c|c|c|c|c|c|c|c|c|c|c|c|}
\hline & [1] & {$[2]$} & [3] & [4] & {$[5]$} & [6] & [7] & [8] & [9] & {$[10]$} & [11] & [12] \\
\hline \multicolumn{13}{|l|}{ Panel A. Full sample: } \\
\hline Conflict region*Victimized & $\begin{array}{c}-1.134 * \\
(0.573)\end{array}$ & $\begin{array}{c}-2.187 * * * \\
(0.643)\end{array}$ & $\begin{array}{c}-1.138 * * \\
(0.537)\end{array}$ & $\begin{array}{c}-2.035^{* * *} \\
(0.592)\end{array}$ & $\begin{array}{c}-1.446 * * \\
(0.507)\end{array}$ & $\begin{array}{c}-2.475 * * * \\
(0.715)\end{array}$ & $\begin{array}{c}-1.783 * * * \\
(0.513)\end{array}$ & $\begin{array}{c}-2.859 * * * \\
(0.638)\end{array}$ & $\begin{array}{c}-1.860 * * * \\
(0.465)\end{array}$ & $\begin{array}{c}-2.747 * * * \\
(0.553)\end{array}$ & $\begin{array}{c}-2.028 * * * \\
(0.508)\end{array}$ & $\begin{array}{c}-3.112 * * * \\
(0.716)\end{array}$ \\
\hline Victimized & $\begin{array}{c}0.121 \\
(0.442)\end{array}$ & $\begin{array}{c}0.405 \\
(0.516)\end{array}$ & $\begin{array}{c}0.012 \\
(0.383)\end{array}$ & $\begin{array}{c}0.281 \\
(0.488)\end{array}$ & $\begin{array}{c}0.056 \\
(0.386)\end{array}$ & $\begin{array}{c}0.407 \\
(0.556)\end{array}$ & $\begin{array}{c}0.447 \\
(0.328)\end{array}$ & $\begin{array}{c}0.608 \\
(0.383)\end{array}$ & $\begin{array}{c}0.276 \\
(0.335)\end{array}$ & $\begin{array}{c}0.402 \\
(0.403)\end{array}$ & $\begin{array}{c}0.342 \\
(0.388)\end{array}$ & $\begin{array}{c}0.576 \\
(0.520)\end{array}$ \\
\hline Conflict region*Victimized $*$ Female & & & & & & & $\begin{array}{c}1.201 \\
(0.865)\end{array}$ & $\begin{array}{c}1.288 \\
(0.943)\end{array}$ & $\begin{array}{c}1.315 \\
(0.830)\end{array}$ & $\begin{array}{c}1.332 \\
(0.863)\end{array}$ & $\begin{array}{c}0.891 \\
(0.883)\end{array}$ & $\begin{array}{c}1.019 \\
(0.929)\end{array}$ \\
\hline Observations & 7,673 & 7,673 & 7,594 & 7,594 & 6,835 & 6,835 & 7,673 & 7,673 & 7,594 & 7,594 & 6,835 & 6,835 \\
\hline R-squared & 0.071 & 0.075 & 0.079 & 0.083 & 0.098 & 0.102 & 0.071 & 0.076 & 0.079 & 0.083 & 0.099 & 0.103 \\
\hline \multicolumn{13}{|l|}{ Panel B. Non-migrants: } \\
\hline Conflict region*Victimized & $\begin{array}{l}-0.870 \\
(0.570)\end{array}$ & $\begin{array}{c}-2.196 * * * \\
(0.655)\end{array}$ & $\begin{array}{l}-0.766 \\
(0.592)\end{array}$ & $\begin{array}{c}-1.948^{* * *} \\
(0.663)\end{array}$ & $\begin{array}{c}-1.068 * \\
(0.599)\end{array}$ & $\begin{array}{c}-2.430 * * * \\
(0.746)\end{array}$ & $\begin{array}{c}-1.589 * * \\
(0.646)\end{array}$ & $\begin{array}{c}-2.819 * * * \\
(0.812)\end{array}$ & $\begin{array}{c}-1.516^{* *} \\
(0.660)\end{array}$ & $\begin{array}{c}-2.546^{* * *} \\
(0.805)\end{array}$ & $\begin{array}{c}-1.579 * * \\
(0.592)\end{array}$ & $\begin{array}{c}-2.946 * * * \\
(0.825)\end{array}$ \\
\hline Victimized & $\begin{array}{c}0.002 \\
(0.516)\end{array}$ & $\begin{array}{c}0.413 \\
(0.660)\end{array}$ & $\begin{array}{l}-0.242 \\
(0.478)\end{array}$ & $\begin{array}{c}0.179 \\
(0.619)\end{array}$ & $\begin{array}{l}-0.168 \\
(0.495)\end{array}$ & $\begin{array}{c}0.505 \\
(0.615)\end{array}$ & $\begin{array}{c}0.302 \\
(0.553)\end{array}$ & $\begin{array}{c}0.444 \\
(0.670)\end{array}$ & $\begin{array}{l}-0.056 \\
(0.602)\end{array}$ & $\begin{array}{c}0.087 \\
(0.708)\end{array}$ & $\begin{array}{c}0.053 \\
(0.557)\end{array}$ & $\begin{array}{c}0.524 \\
(0.639)\end{array}$ \\
\hline Conflict region*Victimized $*$ Female & & & & & & & $\begin{array}{c}1.368 \\
(1.215)\end{array}$ & $\begin{array}{c}1.215 \\
(1.274)\end{array}$ & $\begin{array}{c}1.426 \\
(1.176)\end{array}$ & $\begin{array}{c}1.155 \\
(1.224)\end{array}$ & $\begin{array}{c}0.809 \\
(1.208)\end{array}$ & $\begin{array}{c}0.823 \\
(1.306)\end{array}$ \\
\hline $\begin{array}{l}\text { Observations } \\
\text { R-squared }\end{array}$ & $\begin{array}{l}5,816 \\
0.061\end{array}$ & $\begin{array}{l}5,816 \\
0.066\end{array}$ & $\begin{array}{l}5,757 \\
0.070\end{array}$ & $\begin{array}{l}5,757 \\
0.075\end{array}$ & $\begin{array}{l}5,144 \\
0.084\end{array}$ & $\begin{array}{l}5,144 \\
0.089\end{array}$ & $\begin{array}{l}5,816 \\
0.061\end{array}$ & $\begin{array}{l}5,816 \\
0.066\end{array}$ & $\begin{array}{l}5,757 \\
0.070\end{array}$ & $\begin{array}{l}5,757 \\
0.075\end{array}$ & $\begin{array}{l}5,144 \\
0.085\end{array}$ & $\begin{array}{l}5,144 \\
0.090\end{array}$ \\
\hline \multicolumn{13}{|c|}{ p-value test of equality of coefficients on "Conflict Region *Victimized" for migrant vs. non-migrant households } \\
\hline & 0.692 & 0.635 & 0.648 & 0.576 & 0.993 & 0.927 & 0.736 & 0.673 & 0.728 & 0.645 & 0.891 & 0.971 \\
\hline Province specific trends & no & yes & no & yes & no & yes & no & yes & no & yes & no & yes \\
\hline Child controls & no & no & yes & yes & yes & yes & no & no & yes & yes & yes & yes \\
\hline Household head controls & no & no & yes & yes & no & no & no & no & yes & yes & no & no \\
\hline Mother controls & no & no & no & no & yes & yes & no & no & no & no & yes & yes \\
\hline
\end{tabular}

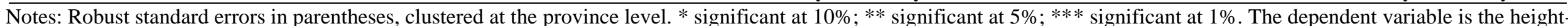

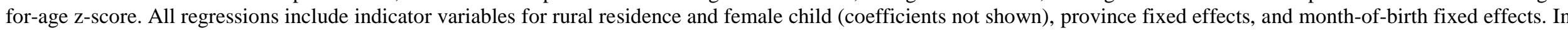

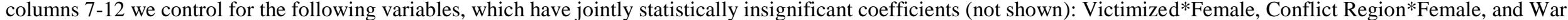

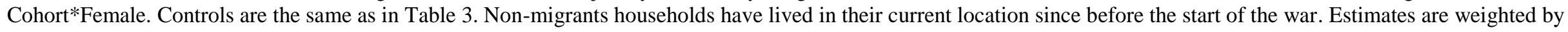
inverse sampling probability. Data sources: 2002 and 2008 Côte d'Ivoire HLSS, and Raleigh et al. (2010). 